\title{
Hydrothermal mineral assemblages of calcite and dolomite-analcime-pyrite in Permian lacustrine Lucaogou mudstones, eastern Junggar Basin, Northwest China
}

\author{
Hong $\mathrm{Li}^{1,2}$ (D) Yiqun $\mathrm{Liu}^{1,2} \cdot$ Kang $\mathrm{Yang}^{2} \cdot$ Yongjie $\mathrm{Liu}^{2} \cdot{\text { Yuanzhe } \mathrm{Niu}^{2}}^{2}$ \\ Received: 23 February 2020 / Accepted: 15 October 2020 / Published online: 27 November 2020 \\ (C) The Author(s) 2020
}

\begin{abstract}
The eastern Junggar Basin, controlled by continental extension (rift), was deposited by lacustrine dominated sediments during middle Permian Lucaogou period. An unusual porphyritic-like texture was observed in Lucaogou/Pingdiquan dark fine-grained organic-rich sediments in two sub-tectonic units in the basin. The "phenocrysts" are composed of two types of mineral assemblages. The first is a coarse euhedral calcite assemblage in the Jimusar Sag, and the second consists of dolomite, analcime, and pyrite in the Shishugou Sag. The lithological and mineralogical features indicate a hydrothermal origin for these phenocryst-like minerals. The chondrite-normalized rare earth element patterns show flat or positive $\mathrm{Ce}$ anomalies and negative Eu anomalies, which reflect a suboxic to anoxic, off-axis site from the center of the fault system, where the temperature of the hydrothermal fluid might be less than $250^{\circ} \mathrm{C}$. The high ratios of $\mathrm{Ba}_{\mathrm{N}} / \mathrm{La}_{\mathrm{N}}$ at 1.6-65.5, strongly positive $\mathrm{Sr}$ anomalies at $\mathrm{Sr} / \mathrm{Sr} *=5.54-39.9$, and relatively low ${ }^{87} \mathrm{Sr} /{ }^{86} \mathrm{Sr}$ isotopes at $0.705002-0.705776$ in the coarse calcite suggest an origin of mixed sources of lake water, underlying biogenetic sediments, and deep magmatic water. However, the low ${ }^{87} \mathrm{Sr} /{ }^{86} \mathrm{Sr}$ ratios of $0.705321-0.705968$ in the dolomite and $\delta^{34} \mathrm{~S}_{\mathrm{V}-\mathrm{CDT}}$ of $10.8 \%$ - $12.3 \%$ in the pyrite indicate that water-underlying-rock interaction and the abiotic thermochemical sulfate reduction of lake water or organic matter might have participated together resulting in the precipitation of the dolomite-analcime-pyrite assemblages in the Shishugou Sag.
\end{abstract}

Keywords Coarse calcite assemblage $\cdot$ dolomite $\cdot$ Analcime $\cdot$ Pyrite $\cdot$ REE geochemistry $\cdot$ in situ strontium isotopes $\cdot$ in situ sulfur isotopes $\cdot$ Lucaogou Formation

\section{Introduction}

Modern global ocean explorations have revealed hundreds of submarine hydrothermal venting sites spread across the ocean floors, which continue to increase in number (Baker et al. 2016; Baker 2017). With a few exceptions, most of the marine hydrothermal locations show close relationships with middle

Editorial handling: Q. Li

Hong Li

lihong2008@nwu.edu.cn

1 State Key Laboratory of Continental Dynamics, Northwest University, Xi'an, WA 710069, China

2 Department of Geology, Northwest University, 229\# North Taibai Raod, Beilin District, Xi'an 710069, Shaanxi Province, China ocean ridges, arcs, and back-arc spreading ridges (Baker et al. 2016; German et al. 2016). The hot hydrothermal fluids from vents not only bring heat and chemical ions to ambient seawater and create deposits of massive mineral assemblages, known as black sulfide-hosted and white carbonate-hosted smokers or chimneys, they also have great biological and ecological significance (Edmond 1981; Klinkhammer et al. 1983; Takai and Horikoshi 1999; Campbell 2006; Martin et al. 2008; Fallon et al. 2017). For the investigation of past stratigraphic records, sedimentary exhalative (SEDEX) deposits characterized by the polymetallic mineralization of mainly $\mathrm{Zn}, \mathrm{Pb}, \mathrm{Ag}, \mathrm{Au}, \mathrm{Cu}$, and $\mathrm{Cd}$ are usually considered to be the most important products of submarine hydrothermal activity (Han and Sun 1999; Lyons et al. 2006).

In comparison with numerous submarine hydrothermal fields, modern terrestrial hydrothermal sites have received relatively little research attention. Instead, relevant studies have focused mainly on Yellowstone National Park in Wyoming, 
USA; the East African Rift system; Lake Baikal, Siberia; and New Zealand, where the geological settings are controlled by the volcanic activities or fault zones of continental rift systems (Fournier 1989; Shanks III and Callender 1992; Tiercelin et al. 1993; Jones et al. 2007; Dekov et al. 2014; Stucker et al. 2016).

The investigations on ancient continental hydrothermal events are even rarer than their modern analogues. However, a few publications have recently reported ancient hydrothermal activities found in lacustrine successions in some oil and gasbearing basins in China, such as those in the Lower Cretaceous Xiagou Formation in Jiuxi Basin, Upper Triassic Yanchang Formation in Ordos Basin, Cretaceous Tenggeer Formation in Erlian Basin, and Middle Permian Lucaogou Formation in northern Xinjiang (Zheng et al. 2006; Liu et al. 2010, 2012; Wen et al. 2013; Zhong et al. 2015; He et al. 2016). One common feature of lacustrine hydrothermal-related minerals is that they appear in organic-rich profundal fine- to very fine-grained sediments in continental rift or active tectonic basins. In addition, very complicated hydrothermal minerals or mineral assemblages are usually observed, such as calcite, dolomite, ankerite, analcime, alkaline feldspar, albite, dickite, quartz, barite, pyrite; however, they lack polymetallic ores. For example, in Jiuxi Basin, the layers of ankerite, albite, quartz, barite, analcime, and dickite are considered to be sub lacustrine white smoker-type exhalative rocks, where the hydrothermal fluid originated mainly from deep magmatic water (Zheng et al. 2006). In Santanghu Basin, fine-grained detrital minerals and lithic grains of the Lucaogou Formation have been interpreted as hydrovolcanic deposits with the alteration of syndepositional hydrothermal fluids (Jiao et al. 2018). In the eastern Junggar Basin, coarse calcite, dolomite, analcime, and pyrite assemblages are considered to be the products of the interaction between hydrothermal fluid and the underlying rocks ( $\mathrm{Li}$ et al. 2017). In the Erlian Basin, four types of fine-to-coarse dolomite, natrolite, analcime, and Fe-bearing magnesite in the lower Cretaceous are believed to be syn-sedimentary hydrothermal products in the Baiyinchagan Sag (Yang et al. 2020). Moreover, some sparry calcite and pyrite in Lucaogou dark mudstones in the Santanghu and Junggar basins have been interpreted as evaporative gypsum pseudomorphs with a suspected hydrothermal origin (Hackley et al. 2016; Qiu et al. 2016a; Wu et al. 2016). These cases indicate that many uncertainties and conflicting opinions remain on the identification of hydrothermal minerals and the explanation of their origins. Therefore, additional research is needed to explore the detailed processes of ancient sublacustrine hydrothermal activities to evaluate their potential economic and scientific significance.

Herein, an unusual porphyritic-like texture was observed in lacustrine black and dark gray mudstones and the shales of the middle Permian Lucaogou Formation in the Jimusar and Shishugou sags, in the eastern Junggar Basin, Northwest China. The phenocryst-like minerals present include coarse calcite, dolomite, analcime, and pyrite, which might reflect hydrothermal activity in an ancient sublacustrine environment. Similar textures have been reported as bladed calcite and pyrite in Lucaogou dark mudrocks in the Malang Sag, Santanghu Basin (Fig. 15 C in Hackley et al. 2016), and as sparry calcite in the Jimusar Sag, eastern Junggar Basin (Fig. 9 A and B in Wu et al. 2016; Fig. 4 G in Qiu et al. 2016b), which have been interpreted as evaporative texture and gypsum pseudomorphs, respectively. However, no other confirmed evaporative evidence has been found in these areas, such as desiccation cracks or red clays. Instead, the surrounding thick dark gray mudstones, black shales, and organic geochemistry indicate a relatively deep lake environment as the sedimentation center in the Jimusar Sag (Carroll 1998; Liu et al. 2017, 2018; Gao et al. 2020). A detailed paleoclimate reconstruction in the southern Bogda area by Yang et al. (Yang et al. 2007a; Yang et al. 2010) indicates oscillating climatic conditions in the Lucaogou period from subhumid to semiarid and even semiarid to arid. A recent study by Gao et al. (2020) mapped the distribution of the paleoclimatic indicators in the Junggar Basin and adjacent Turpan Basin in the Permian period and found that evaporite minerals were mainly formed in the Early Permian, whereas humid climate indicators such as coals and Angaran Flora predominated in the Middle-Late Permian; hence, they proposed a drier regional paleoclimate over the Junggar Basin in the Early Permian and a more humid one in the Middle-Late Permian with short-term climatic fluctuations. Therefore, it is dubious to link the sparry calcite in the Lucaogou dark mudstones to evaporative gypsum under an arid paleoclimate. In this study, we attempt to provide a detailed overview of the mineralogical and lithological features as well as the geochemical data of the phenocryst-like minerals to discuss their possible origins and fluid sources.

\section{Geological setting}

The Junggar Basin covers an area of approximately $136,000 \mathrm{~km}^{2}$ and is located among the Siberian, Kazakhstan plates and the Tianshan fold belt (Li et al. 1992; Liang et al. 2016). It is a large superimposed basin experiencing complicated tectonic evolution with abundant natural resources in north Xinjiang, northwestern China (Fang et al. 2019; Fig. 1 a). The study area lies in the Shishugou and Jimusar sags, two secondary tectonic units in the eastern Junggar Basin (Fig. 1 b).

The Late Paleozoic Carboniferous and Permian periods represent a critical time of ocean-continent transition in the eastern Junggar area (Li et al. 1992). Differing opinions have been reported on the tectonic activity in this area, such as the settings of post-collision (Han et al. 2006; Xiao et al. 2008; Yang et al. 2010; Fang et al. 2019), continental rift (Li et al. 1992; Zheng et al. 2000; Wang et al. 2016), and subductionrelated arc settings (Xie et al. 2016). However, it is widely 

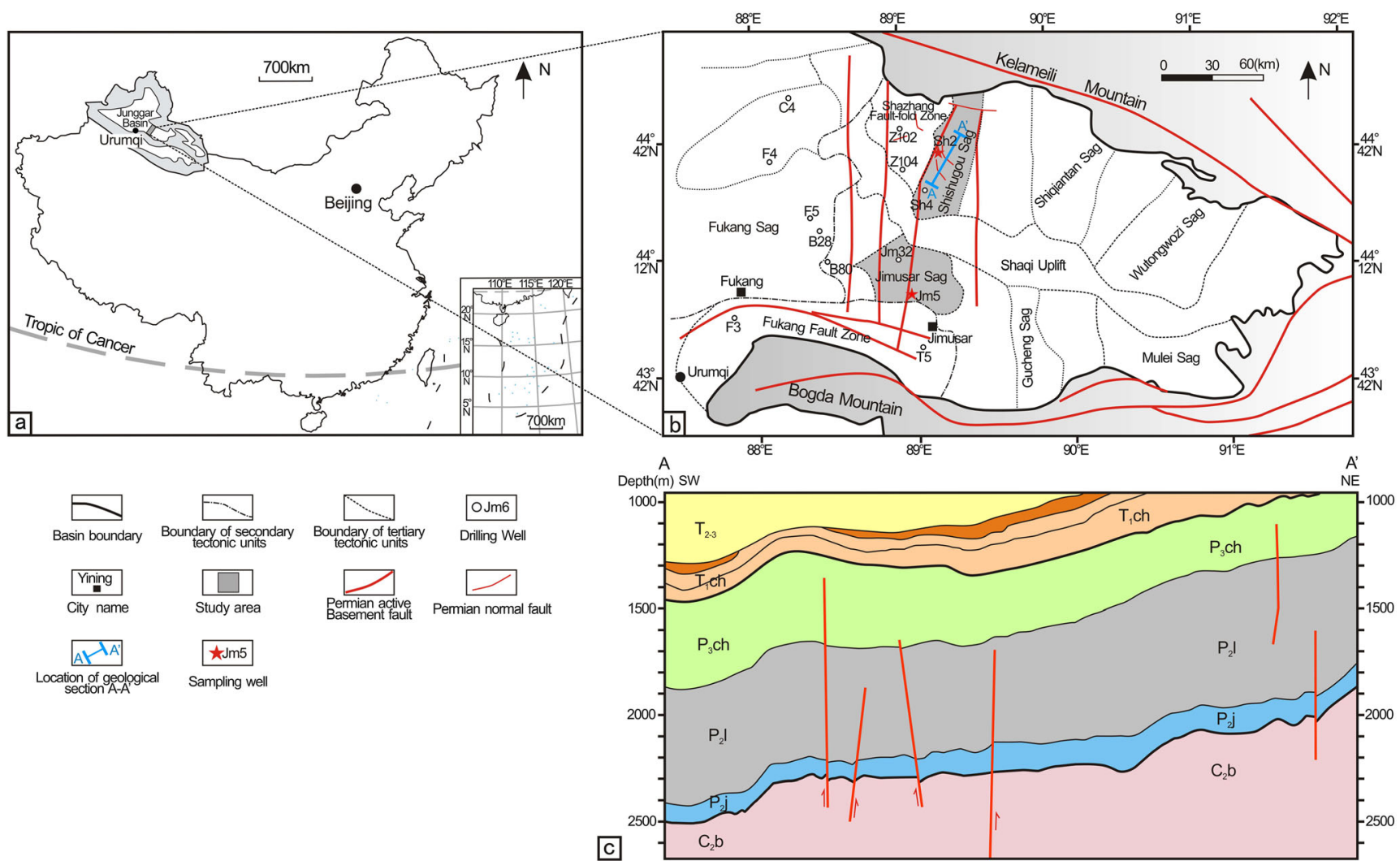

Fig. 1 Location and geological map of eastern Junggar Basin. (a) Simplified map of the study area in Junggar Basin. The tectonic units in (b) are from Jin et al. (2018). The Permian active basement faults in (b)

are from Qu et al. (2008a, 2008b). The geological cross-section A-A' in (c) is from unpublished material of Xinjiang Oilfield Co.

accepted that the eastern Junggar area was under the control of a continental extensional background during the late Carboniferous and early-middle Permian period ( $\mathrm{Li}$ and Xiao 1999; Xu et al. 2014).

The upper Carboniferous and lower Permian rocks in the eastern Junggar area are composed of widespread basic to acidic calc-alkaline and alkaline igneous rocks such as basalts, alkali basalts, andesites, granites, alkali granites, and volcaniclastic rocks, alternating with normal sedimentary beds of shallow marine to terrestrial sediments (Carroll 1998; Han et al. 2006; Yang et al. 2009; Gan et al. 2010; Su et al. 2010). In the Shishugou Sag, drilling cores have revealed that the upper Carboniferous unit is composed mainly of approximately $300 \mathrm{~m}$ of gray conglomerates; green, gray, and reddish andesites; and volcanic breccias. In the southern part of the research area, no drilling wells have reached strata older than the Lucaogou Formation. However, regional geological surveys and an examination of the surrounding outcrops indicate that the upper Carboniferous and lower Permian rocks feature basaltic andesite, pillow basaltic lava, relatively shallow to deep marine carbonate rocks, and carbonate-volcaniclastic turbidites in and around the Bogda region (Carroll et al. 1990; Xie et al. 2016).

The research area in the middle Permian period was dominated by relatively quiet sedimentation rather than active volcanic activities, but was still situated in the continental

extension (rift) stage (Meng et al. 1992; Yang et al. 2007b). The lithological successions of the middle Permian Jiangjunmiao and Lucaogou/Pingdiquan formations are characterized by thick black and dark gray organic-rich shales/ mudstones and sandstones interbedded with relatively thin layers of tuffs and microcrystalline limestones and dolomites, indicating a terrestrial semi-deep to deep lacustrine environment with huge hydrocarbon source potential (Li 2004; Jiang et al. 2015). In particular, the thick black shales/mudstones of the Lucaogou Formation, with high total organic carbon (TOC) and abundant organic matter, are considered as a "world class source rock" and potential tight oil reservoirs in both the Junggar and Santanghu basins in northern Xinjiang (Carroll 1998; Liu et al. 2017, 2018; Zou et al. 2019). For example, in the Shishugou Sag, the Lucaogou Formation in Well Sh2 is composed of $480 \mathrm{~m}$ of gray fine-grained sandstones, argillaceous sandstones, calcareous sandstones, siltstones, and tuffaceous siltstones interbedded with dark gray mudstones, silty mudstones, tuffaceous mudstones, and dolomitic mudstones (Fig. 1 c, Fig. 2 a). However, in the Jimusar Sag, the thickness of the Lucaogou Formation is decreased to $378 \mathrm{~m}$ in Well Jm5. Moreover, the grain size of the sediments is finer than that in the Shishugou Sag, and the rocks include thick dark gray mudstones, dolomitic mudstones, medium to thin layers of dolomite, and dolomitic siltstones (Fig. 2 b). 


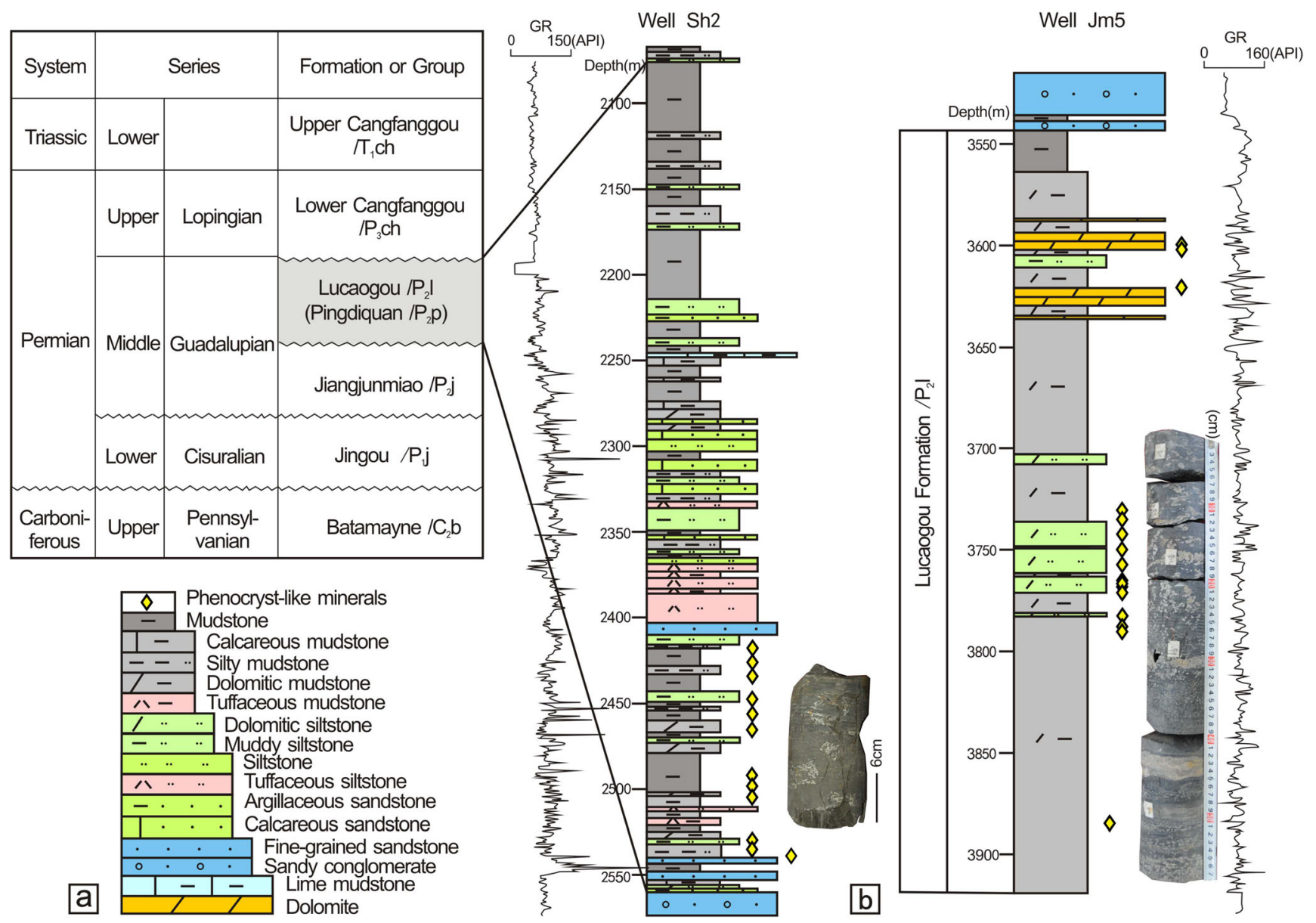

Fig. 2 Lithological columns of Lucaogou Formation in the study area. (a) Lithological column of Lucaogou Formation in Well Sh2, Shishugou Sag. (b) Lithological column of Lucaogou Formation in Well Jm5, Jimusar Sag

Qu et al. (2008a, 2008b) mapped the main fault systems in and around Junggar Basin by using seismic tomography, twodimensional and three-dimensional seismic sections, and field investigations. They observed several $\mathrm{S}-\mathrm{N}$ and $\mathrm{E}-\mathrm{W}$ fault belts cutting through the basement of the eastern part of the Junggar Basin, most of which were active in the Permian $(\mathrm{Qu}$ et al. 2008a, 2008b; Fig. 1 b). As shown in Fig. 1 c, the A-A' geological section in the Shishugou Sag reveals that the Permian fault systems were mainly built up by high-angle normal faults, which coincides with the tectonic extensional background.

\section{Samples and methods}

The specimens analyzed in this study were collected from two drilling cores, one from the Shishugou Sag and the other from the Jimusar Sag in the eastern Junggar Basin. The specimens of the Jimusar Sag were taken from the interval of 3731.42 to $3791.35 \mathrm{~m}$ in Well Jm5 and those of the Shishugou Sag were taken from 2414.88 to $2538.33 \mathrm{~m}$ in Well Sha2. All the samples were collected from dark gray mudstone and dolomitic mudstone of the Permian Lucaogou Formation, also known as the Pingdiquan Formation, from which the phenocryst-like minerals are the most abundant and evident (Fig. 2).

Optical microscope-cathodoluminescence (OM-CL, Götze et al. 2013) imaging was used for mineralogical and petrological investigations. The CL images were obtained using a Nikon-LV100-POL polarizing microscope equipped with a BII cathodoluminescent Model CLF-1 unit (BEACON INNOVATION INTL INC.) at $15 \mathrm{keV}$ and a $260 \mu \mathrm{A}$ electron current.

Major element analysis, in situ trace and rare earth element (REE) analysis, and in situ $\mathrm{Sr}$ and $\mathrm{S}$ isotope analysis were performed for all samples. The mineral chemical compositions of major elements were identified by using an electron microprobe micro-analyzer (EPMA). Thin sections of the samples were carbon coated and analyzed by the EPMA analyzer (JXA8230, Japan Electronics Co. LTD) with a $15 \mathrm{keV}$ electron beam of $10 \mu \mathrm{m}$ for carbonate minerals and $10 \mathrm{nA}$ for the spot analysis of pyrite and analcime. The details of mineral analysis conditions are listed in the electronic supplementary material (ESM) in Table S1. 
In situ trace and REEs were measured by laser ablationinductively coupled plasma-mass spectrometry (LA-ICPMS). The details of the experimental instruments and conditions have been described by Liu et al. (2007). Under the same LA-ICP-MS operating conditions, the trace elements and REEs of the reference material BCR-2G (melted natural basalt glass from the US Geological Survey (USGS), Gao et al. 2002), NIST SMR 610 (synthetic silicate glass from the National Institute of Standards and Technology (NIST), Gao et al. 2002), and GSE-1G (synthetic basaltic glass from the USGS, Jochum et al. 2005) were also identified. The laser beam for the phenocryst-like calcite was set to $60 \mu \mathrm{m}$ and that for the dolomite, analcime, and pyrite "phenocrysts" was set to $44 \mu \mathrm{m}$.

In situ $\mathrm{S}$ isotopes of the phenocryst-like pyrites were analyzed by femtosecond laser ablation-coupled multi-collectorinductively coupled plasma-mass spectrometry (FsLA-MCICP-MS), involving the employment of a Laser ablation system (RESOlution M-50, ASI) equipped with a $193 \mathrm{~nm}$ ArF excimer laser (CompexPro 102, Coherent), a large double-cell sample chamber, and a computer-controlled high-precision X-Y sample positioning stage. Then, the above LA system was connected to an MC-ICPMS instrument (Plasma 1700, Nu Instruments) to measure the $\mathrm{S}$ isotopes. The details of the experimental instruments and conditions are described in Chen et al. 2017. During the testing process, the $\mathrm{S}$ isotope of a coarse-grained pyrite (Py$4, \delta^{34} \mathrm{~S}_{\mathrm{V}-\mathrm{CDT}}=1.7 \pm 0.30 \%$, Chen et al. 2019) was also determined as an external reference for calibration by using a laser with a beam of $20-37 \mu \mathrm{m}$ in diameter.

In situ $\mathrm{Sr}$ isotopes of the phenocryst-like calcite and dolomite were also analyzed by FsLA-MC-ICPMS. The LA system was the same as that used for $\mathrm{S}$ isotopes and was connected to an MC-ICPMS instrument (Plasma II, Nu Instruments) for measurement. During the testing, the $\mathrm{Sr}$ isotopes of the reference material LXH with a value of ${ }^{87} \mathrm{Sr} /{ }^{86} \mathrm{Sr}=0.709210$ were determined under the same experimental conditions, and the laser beam was set to $20-53 \mu \mathrm{m}$. The details of the experimental instruments and conditions are described in the study by Bao et al. (2017).

\section{Results}

\section{Lithology and mineralogy}

In the research area, the "porphyritic" sedimentary rocks of the Middle Permian Lucaogou Formation were found mainly in the drilling cores of the Shazhang fault-fold zone, the Shishugou Sag, and the Jimusar Sag, in the eastern Junggar Basin (Fig. 1 b). In the vertical direction, the presence of the "porphyritic" textures is discontinuous throughout the Lucaogou Formation and they occur most commonly in the very fine-grained sediments of the lower part (Fig. 2). They consist of two compositional textures of the "phenocrysts" and "matrix," which is similar to the porphyritic texture observed in volcanic rocks (ESM; Fig. S1). However, the compositions of both the "phenocrysts" and the "matrix" are evidently different from the volcanic rock counterparts. According to the drilling core observation, the "phenocrysts" are composed mainly of coarse calcite, dolomite, analcime, and pyrite and are dispersed randomly as snowflakes, mottling, or irregular twigs in the matrix. Some of these crystals have sufficient density to form several continuous or discontinuous white or light fawn laminae at $0.5-5 \mathrm{~cm}$ in thickness (ESM; Fig. S1 a, b).

The "matrix" is composed of silt- and clay-sized organicrich terrestrial sediments or microcrystalline dolomite and is consistent with the overlying and underlying sedimentary rocks, such as black or dark gray shales, mudstones, siltstones, lime mudstones, and microcrystalline dolomite that are all sometimes mixed with thin layers of fine-grained sandstones and tuffs (ESM; Fig. S1). The fragments of fossil plants, fish scales, ostracods, and bivalves are occasionally found in overlying and underlying rocks, which indicates a semi-deep to deep lake environment. High-angle fractures are also found in the mudstones containing the "phenocrysts" and in the surrounding rocks (ESM; Fig. S1 a, c).

Microscopic observations revealed that the "phenocrysts" have two typical forms: single mineral collections or several syngenetic mineral assemblages. For example, coarse calcite was found in the Jimusar Sag in Well Jm5, and the assemblage of dolomite, analcime, and pyrite was found in the Shishugou Sag in Well Sh2.

Jimusar sag The "phenocrysts" are generally composed of $0.3-1 \mathrm{~mm}$ single euhedral calcite crystals in Well Jm5. Cleavage in one or two directions as well as polysynthetic twinning was observed under the microscope (Fig. 3). The matrix is composed of dark gray silty mudstone with thin laminae. The calcite "phenocrysts" are usually surrounded by slightly curved sedimentary laminae (Fig. $3 \mathrm{~b}$, g).

In the OM-CL image, the coarse calcite was generally distinguished by two stages (Stage I and Stage II). Stage I calcite is composed of a euhedral non-luminescent core and zonings of narrow orange with relatively wide dull orange bands (white arrows in Fig. $3 \mathrm{c}-\mathrm{f}$ ). The Stage II calcite exhibits bright orange luminescence and irregularly overlies the surface of Stage I calcite or grew at the edge of it (white dotted arrows in Fig. $3 \mathrm{c}-\mathrm{f}$ ). However, only part of the calcite crystals showed a zoning texture in the backscatter images (Fig. $3 \mathrm{~g}$ ); otherwise, no conspicuous zoning features were observed (Fig. $3 \mathrm{~h}$ ).

Shishugou sag The "phenocrysts" in Well Sha2 are syngenetic assemblages of three minerals: dolomite, analcime, and pyrite (Fig. 4). The dolomite "phenocryst" is yellowish and mostly 

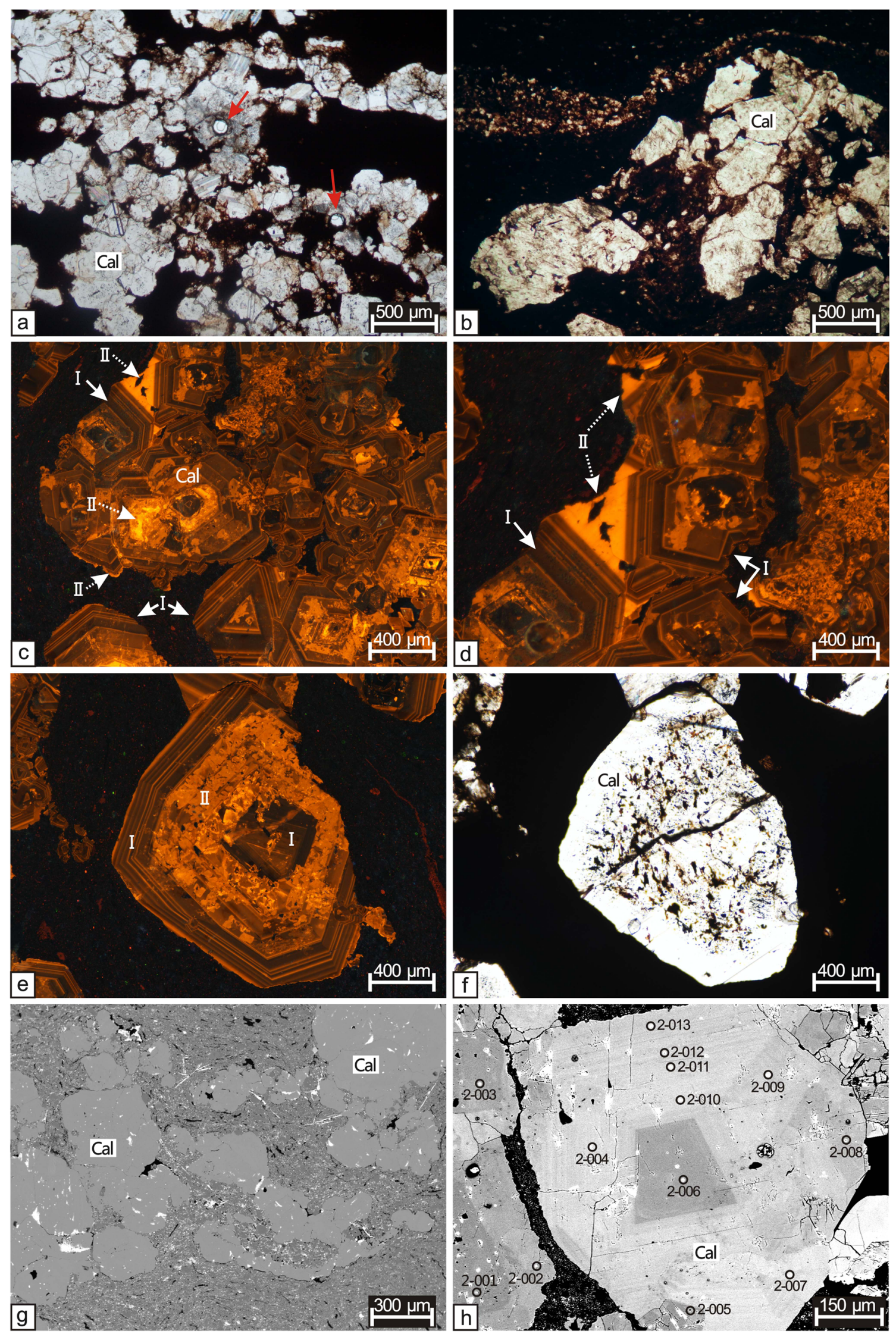
Fig. 3 Coarse calcite assemblages in Lucaogou Formation in Well Jm5, Jimusar Sag. (a) (b) (f) are plane-polarized transmitted-light images. (a) Coarse calcite assemblages (Cal) in dark mudstone. Red arrows indicate the laser ablation spots of in situ analysis. (b) The "matrix" is composed of silt and clay-sized sediments. The calcite assemblages are surrounded by sedimentary laminae, which indicate that they were formed prior to the diagenesis of mechanical compression. (c) (d) (e) OM-CL images show two stages of the calcite. Stage I calcite consists of an inner nonluminescent core and outer oscillatory zoning (white arrows). Stage II calcite shows bright orange color, either overlying the surface or as growth on the edge of the Stage I calcite (white dotted arrows). The oscillatory zonings of Stage I calcite indicate a primary texture of crystallization. (f) Phenocryst-like calcite, the same calcite crystal of image (e). (g) and (h) are back scattered electron (BSE) images. The calcite in (g) shows no zoning texture and is surrounded by sedimentary laminae, whereas that in (h) exhibits zoning texture. Nos. 2-001 to 2-013 are EPMA spots (corresponding to the spot number in Table 1)

euhedral with single sizes of $0.2 \mathrm{~mm}$ to $1.2 \mathrm{~mm}$ (Fig. $4 \mathrm{a}, \mathrm{b}, \mathrm{c}$, e). The analcime is colorless and transparent with radial or amorphous forms under the microscope and shows complete extinction under cross-polarized light (Fig. 4 c, d, e, f). The pyrite is opaque under polarized light but shows a bright color in the backscattered images (Fig. 4). The "matrix" is composed of black-brown silty mudstone with abundant laminae of compressed and elongated organic matter (Fig. 4 a, b). The "phenocrysts" of dolomite, analcime, and pyrite are nonluminescent under OM-CL.

\section{Major element compositions}

The major element compositions of the phenocryst-like calcite $\left(\mathrm{CaCO}_{3}\right)$ identified by EPMA testing are listed in Table 1 . The calcite in Well Jm5 is relatively abundant in $\mathrm{Ca}, \mathrm{Mg}$, and $\mathrm{Fe}$ elements. The content of $\mathrm{CaO}$ ranges from $50.0 \mathrm{wt} \%$ to $55.6 \mathrm{wt} \%$ with an average of $53.8 \mathrm{wt} \%$, based on 42 points. The contents of $\mathrm{MgO}$ and $\mathrm{FeO}$ are $0.03-$ $0.50 \mathrm{wt} \%$ and $\sim 0.42 \mathrm{wt} \%$, with averages of $0.21 \mathrm{wt} \%$ and $0.14 \mathrm{wt} \%$, respectively. $\mathrm{No} \mathrm{SiO}_{2}$ was detected in the calcite, and the contents of $\mathrm{Al}_{2} \mathrm{O}_{3}, \mathrm{TiO}_{2}$, and $\mathrm{SO}_{3}$ were poor, with averages of $0.01 \mathrm{wt} \%, 0.01 \mathrm{wt} \%$, and $0.02 \mathrm{wt} \%$, respectively.

The major element compositions of the phenocryst-like dolomite $\left(\mathrm{CaMg}\left(\mathrm{CO}_{3}\right)_{2}\right)$, analcime $\left(\mathrm{NaAlSi}_{2} \mathrm{O}_{6} \cdot \mathrm{H}_{2} \mathrm{O}\right)$, and pyrite $\left(\mathrm{FeS}_{2}\right)$ in Well $\mathrm{Sh} 2$ according to EPMA testing are listed in Tables 2, 3, and 4, respectively. According to the EPMA analysis, the highest elemental content in the phenocryst-like dolomite is Fe, followed by $\mathrm{Mn}$ (Table 2). The content of $\mathrm{CaO}$ varies from $26.5 \mathrm{wt} \%$ to $28.2 \mathrm{wt} \%$, with an average of $27.6 \mathrm{wt} \%$ based on 9 points. The contents of $\mathrm{MgO}, \mathrm{FeO}$, and $\mathrm{MnO}$ are 11.09-14.78 wt\%, 7.27-11.09 wt\%, and 0.13$0.55 \mathrm{wt} \%$, with averages of $12.37 \mathrm{wt} \%, 9.70 \mathrm{wt} \%$, and $0.27 \mathrm{wt} \%$, respectively. $\mathrm{No}_{\mathrm{SiO}_{2}}$ was detected in the ferroan dolomite, and the contents of $\mathrm{Al}_{2} \mathrm{O}_{3}$ and $\mathrm{P}_{2} \mathrm{O}_{5}$ were poor, with averages of $0.01 \mathrm{wt} \%$ and $0.03 \mathrm{wt} \%$, respectively.
The phenocryst-like analcime has very low concentrations of elemental $\mathrm{Ca}, \mathrm{Ti}, \mathrm{Mg}, \mathrm{Mn}$, and $\mathrm{Cr}$ but is relatively rich in $\mathrm{Fe}$ as $\mathrm{FeO}$, with an average of $0.23 \mathrm{wt} \%$ (Table 3). The content of $\mathrm{Na}_{2} \mathrm{O}$ varies in the range $13.06-11.43 \mathrm{wt} \%$ with an average of $12.00 \mathrm{wt} \%$, which is lower than the theoretical $\mathrm{Na}_{2} \mathrm{O}$ content (14.09 wt\%) of analcime. The content of $\mathrm{Al}_{2} \mathrm{O}_{3}$ ranges from $21.4 \mathrm{wt} \%$ to $19.47 \mathrm{wt} \%$ with an average of $20.4 \mathrm{wt} \%$, which is lower than the theoretical $\mathrm{Al}_{2} \mathrm{O}_{3}$ content (23.20 wt\%) of analcime. However, the content of $\mathrm{SiO}_{2}$ ranges from $56.6 \mathrm{wt} \%$ to $58.5 \mathrm{wt} \%$ with an average of $57.6 \mathrm{wt} \%$, which is higher than the theoretical $\mathrm{SiO}_{2}$ content $(54.54 \mathrm{wt} \%)$ of analcime.

The content of $\mathrm{Fe}$ in the pyrite varies in the range 45.7$46.8 \mathrm{wt} \%$ with an average of $46.3 \mathrm{wt} \%$ (Table 4 ) and that of $\mathrm{S}$ ranges from $53.0-54.3 \mathrm{wt} \%$ with an average of $53.5 \mathrm{wt} \%$. The average concentrations (wt\%) of Ni, $\mathrm{Au}, \mathrm{Pb}, \mathrm{Ag}, \mathrm{As}, \mathrm{Zn}, \mathrm{Cu}$, and $\mathrm{Co}$ are 0.01, 0.07, 0.01, 0.02, 0.07, 0.02, 0.01, and 0.07, respectively.

\section{Trace element and REE geochemistry}

The in situ analysis results of trace elements and REEs are listed in Tables 5 and ESM, and in Table S2, respectively. The $\Sigma$ REE of the phenocryst-like calcite ranges from 18.0 to $90.4 \mathrm{ppm}$. The concentration of light REEs (LREEs) from La to Eu varies in the range of 10.9-39.4 ppm and that of heavy REEs (HREE) from Gd to Y varies from 2.89 to $51.3 \mathrm{ppm}$ (Table 5). The chondrite-normalized REE distribution patterns of the calcite are generally flat but show pronounced Eu depletion and a slight enrichment of Ce, Gd, and Yb (Fig. 5; Sun and McDonough 1989). The chondrite-normalized $\delta \mathrm{Eu}$ values of the calcite vary from 0.52 to 0.9 with an average of 0.62. However, the $\mathrm{Eu}$ anomalies disappeared or were slightly positive when normalized by the North American Shale Composite (NASC; Fig. 5; Gromet et al. 1984). The chondrite-normalized $\delta \mathrm{Ce}$ values of the calcite vary from 0.84 to 1.42 with an average of 1.25 . A slightly positive anomaly is shown in both the chondrite- and NASC-normalized REE patterns (Fig. 5).

The SREE of the phenocryst-like dolomite in Well Sh2 ranges from $91.3 \mathrm{ppm}$ to $258 \mathrm{ppm}$, which is higher than those of analcime and pyrite at $\Sigma$ REE $=0.0998 \mathrm{ppm}$ to $6.87 \mathrm{ppm}$ and $\Sigma$ REE $=2.37 \mathrm{ppm}$ to $33.3 \mathrm{ppm}$, respectively (Table 5; ESM; Table S2). The LREE and HREE concentrations of dolomite vary in the range 44.7-152 ppm and 44.6107 ppm, respectively (Table 5). The dolomite shows a slight enrichment in LREE, while showing no $\delta \mathrm{Ce}$ and negative $\delta \mathrm{Eu}$ in both the chondrite- and NASC-normalized REE patterns (Fig. 5). The chondrite-normalized $\delta \mathrm{Eu}$ and $\delta \mathrm{Ce}$ values of the dolomite vary from $0.55-0.6$ and $0.98-1.07$ with averages of 0.58 and 1.02 , respectively (Table 5).

The $\Sigma$ REE in the phenocryst-like analcime had an average of $2.13 \mathrm{ppm}$ which is poor as it is lower than those in the associated dolomite and pyrite. The normalized REE patterns 

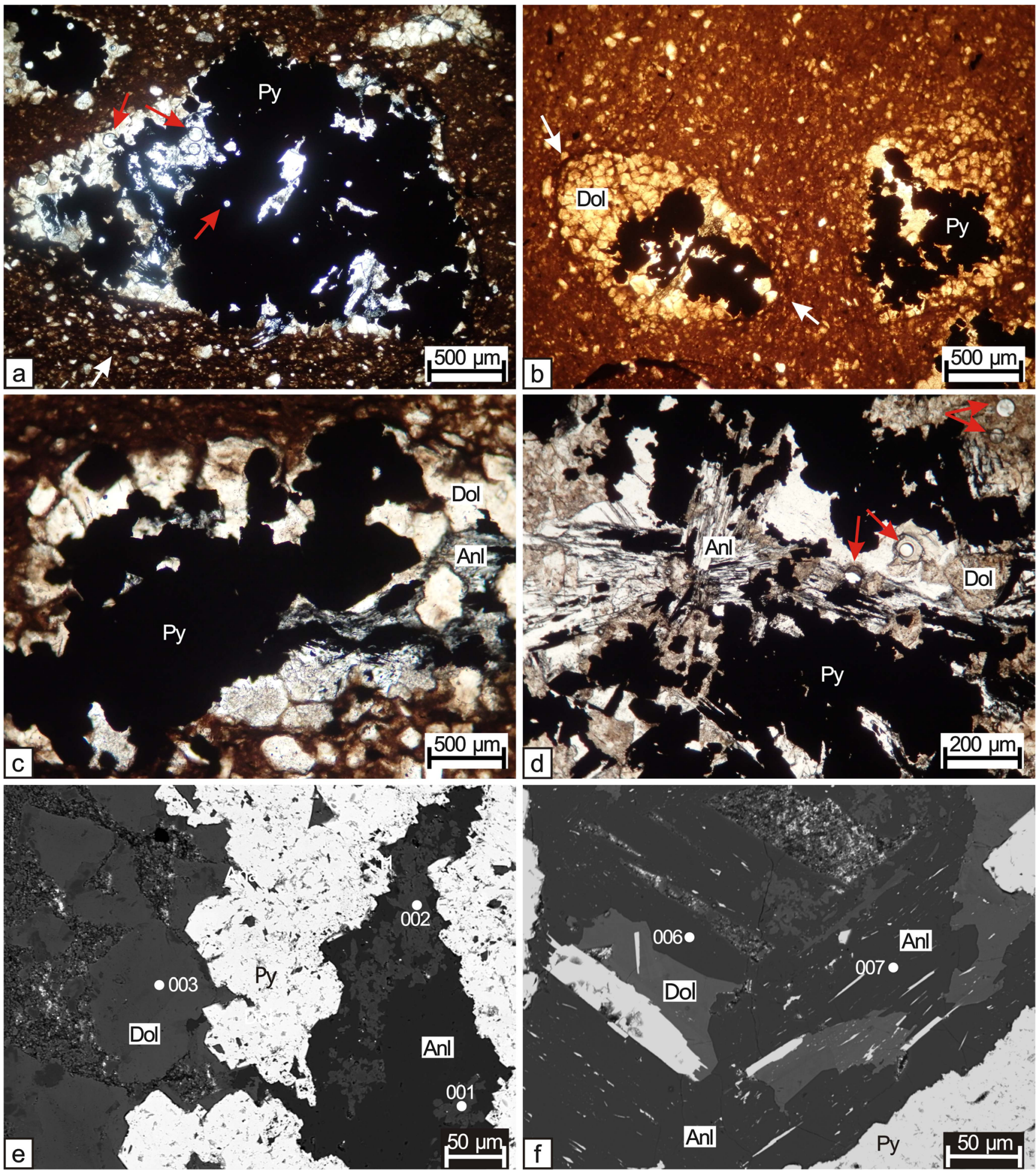

Fig. 4 Phenocryst-like mineral assemblages in Well Sha2, Shishugou Sag. (a) (b) (c) and (d) are plane-polarized transmitted-light images. Phenocryst-like mineral assemblages are composed of dolomite (Dol), analcime (Anl), and pyrite (Py). The "matrix" is composed of silty mudstone rich in organic matter. Red arrows indicate the testing spots of in situ analysis. The white arrows point to brown laminae of organic

matter in the "matrix." (e) and (f) are BSE images. Nos. 001-003 in (e) are EPMA spots of ferroan-rich dolomite (corresponding to spot number in Table 2). Nos. 006 and 007 in (f) are EPMA spots of analcime (corresponding to spot number in Table 3). No distinct evidence shows pore dissolution and filling for these mineral assemblages. For the abbreviations of mineral names see Whitney and Evans 2010

of analcime and pyrite show trends similar to those of the dolomite (Fig. $5 \mathrm{~b}, \mathrm{~d}$ ). The $\delta \mathrm{Eu}$ and $\delta \mathrm{Ce}$ of the pyrite varies

from $0.47-1.74$ and $0.83-1.16$ with averages of 0.71 and 1.0 , respectively (ESM; Table S2). The primitive mantle- 
Table 1 Major-element compositions of calcite in Well Jm5, Jimusar Sag

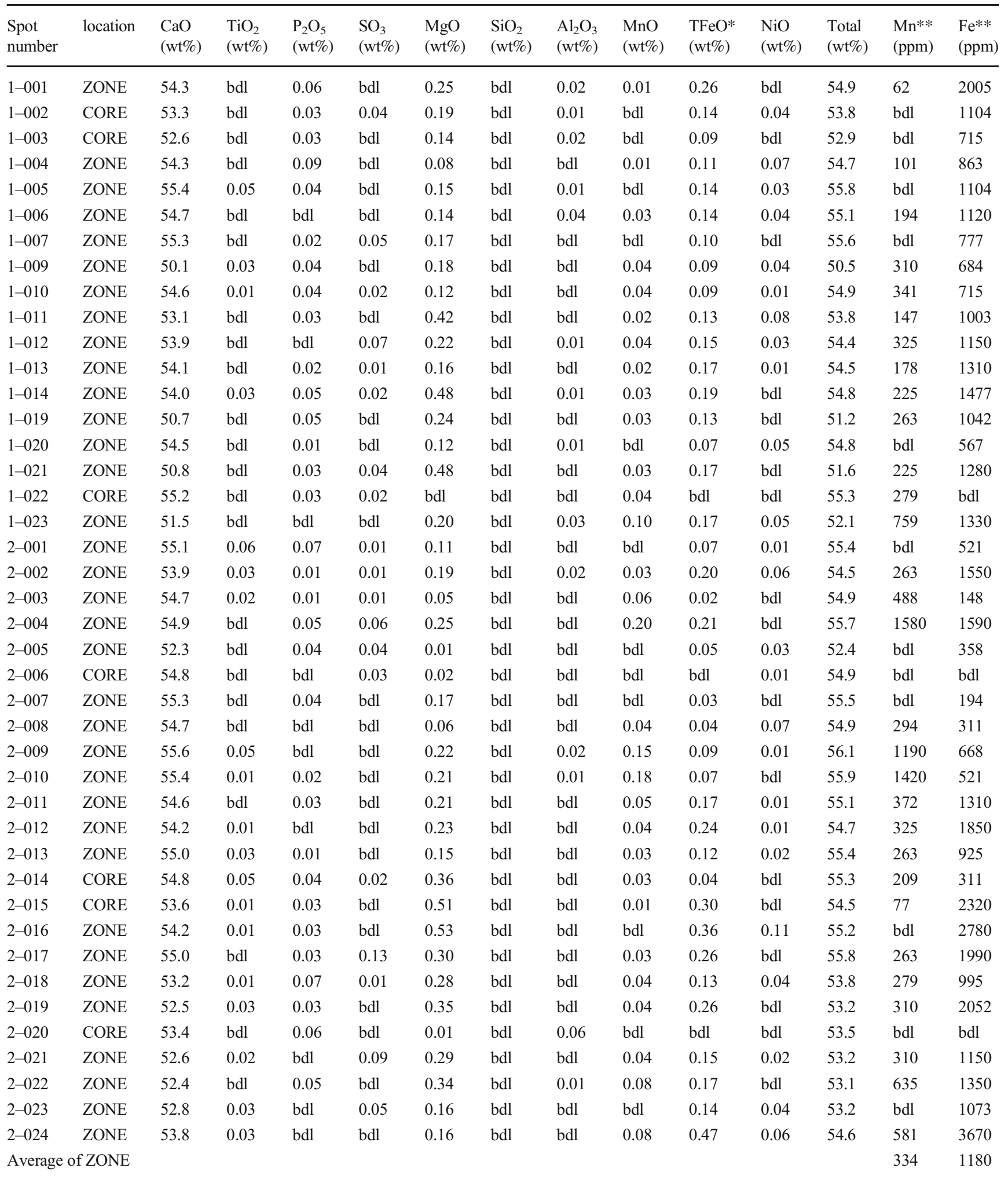

"bdl" means below detection limit

Testing spots 2-001 to 2-013 are labeled in Fig. $3 \mathrm{~h}$

"CORE" means the center part of the calcite crystals; "ZONG" means the zoning texture of the calcite crystals

$\mathrm{TFeO}^{*}=$ amount of both ferric and ferrous iron 
normalized trace element patterns indicate that all the "phenocrysts," including calcite, dolomite, analcime, and pyrite, are rich in the mobile elements of $\mathrm{Cs}, \mathrm{U}, \mathrm{Sr}$, and $\mathrm{Ba}$, but are poor in $\mathrm{K}$ and high field-strength elements (HFSEs) such as $\mathrm{Nb}$, Ta, $\mathrm{Zr}$, Hf, and Ti (ESM; Fig. S2).

Othman et al. (1989) found that the Ba concentrations of $350-800 \mathrm{ppm}$ in marine carbonate-rich biogenic oozes were lower than those in pelagic clay, at $1114-5000 \mathrm{ppm}$ and those in Mn nodules, at 790-2250 ppm; the $\mathrm{Ba}_{\mathrm{N}} / \mathrm{La}_{\mathrm{N}}$ ratios in the $\mathrm{Mn}$ nodules were the highest among the others, and the $\mathrm{La}_{\mathrm{N}} /$ $\mathrm{Sm}_{\mathrm{N}}$ ratios were similar (Fig. 6). The main possible reason for this is the preferential enrichment of alkali and alkaline earth elements such as $\mathrm{K}, \mathrm{Na}, \mathrm{Rb}, \mathrm{Mg}, \mathrm{Ca}, \mathrm{Sr}$, and Ba relative to the REEs in hydrous and hydrothermal fluids (Othman et al. 1989; Langmuir et al. 1997). Although the Jimusar calcite "phenocrysts" have Ba and La concentrations similar to those of Othman's biogenic sediments, they differ significantly from those of Shishugou dolomite, analcime, and pyrite (Table 5 and ESM; Table S2). When the $\mathrm{Ba}_{N} / \mathrm{La}_{\mathrm{N}}$ and $\mathrm{La}_{\mathrm{N}} /$ $\mathrm{Sm}_{\mathrm{N}}$ ratios of the calcite were applied to the figure of Othman shown in Fig. 6 of the present study, most of the data fell in or near the "Biogenic Sediment (BO) zone," and several tended towards the "Pelagic and Hemipelagic Sediment (PHC) zone". However, the ratios of $\mathrm{Ba}_{\mathrm{N}} / \mathrm{La}_{\mathrm{N}}$ and $\mathrm{La}_{\mathrm{N}} / \mathrm{Sm}_{\mathrm{N}}$ in the dolomite, analcime, and pyrite "phenocrysts" are close to Mixing Curve B (which is between a hypothetical mantle composition and the average percent composition for all sediments) and are consistent with those in the basalts in the upper Carboniferous Batamayineishan Formation in the Junggar Basin (Fig. 6; Wu et al. 2009).

\section{In situ Sr isotopes}

The in situ analytical results of the ${ }^{87} \mathrm{Sr} /{ }^{86} \mathrm{Sr}$ ratio in the Lucaogou calcite and dolomite "phenocrysts" are listed in Table 6. Those of the calcite range from $0.705002 \pm$ 0.000020 to $0.705776 \pm 0.000036$ with an average of 0.705361 , and those of the dolomite range from $0.705321 \pm$ 0.000014 to $0.705972 \pm 0.000033$. These ratios are much lower than the lowest value of Permian seawater, at 0.70685 in the Capitanian Stage (Fig. 7; Korte et al. 2006).

\section{In situ $\mathbf{S}$ isotopes}

The in situ testing results of the $\mathrm{S}$ isotopes of the pyrite "phenocryst" are listed in ESM, Table S3. The $\delta^{34} \mathrm{~S}$ values of pyrite in Well Sh2 range from $10.8 \pm 0.14 \%$ o to $12.3 \pm$ $0.16 \%$ o with an average $11.6 \%$. These values fall in the middle zone between the $\delta^{34} \mathrm{~S}$ values for sulfide in mid-ocean ridge basalt (MORB), at $\delta^{34} \mathrm{~S}_{\mathrm{V}-\mathrm{CDT}}=0 \pm 2 \%$ o (Shanks III 2001), and those for seawater sulfate, at $\delta^{34} \mathrm{~S}_{\mathrm{V}-\mathrm{CDT}}=21.0 \pm 0.2 \%$ o (Seal II 2006; Fig. 8).

\section{Discussion}

\section{Geochemical properties of the phenocryst-like minerals}

The REE contents and fractionation patterns between modern lacustrine deposits and lake water show distinct differences when compared from several regions (Fig. 5). Normalized REE patterns of lacustrine microbialites (stromatolites) in Cuatro Ciénegas Bolson, Coahuila, México are enriched in the LREEs relative to the HREEs, revealing a certain amount of inheritance from the lake water (Fig. 6 a, c). The enrichment of HREE in the stromatolites was mainly attributed to the uptake by microbial components from the ambient waters (Johannesson et al. 2014). However, in Abhé Lake, Afar Rift, the large difference in REE concentration and fractionation patterns between the hydrothermal carbonate chimneys and lake water indicate that the chimneys most likely incorporate REEs from both the hydrothemal fluid and the lake water (Dekov et al. 2014). Although there is a lack of REE information on ancient lake water in the Jimusar Sag, normalized REE patterns of Jimusar calcite partly coincide with those of carbonate-rich microbial mats which are formed in shallow lake water with mixed rain, seawater, and $\mathrm{CO}_{2}$-dominated hydrothermal fluids in Venere Lake, Pantelleria Island (Fig. 6 a, c, Censi et al. 2015). While in the Shishugou Sag, normalized REE concentrations and fractionation patterns of dolomite are consistent with those in the syn-sedimentary lacustrine hydrothermal $\mathrm{Md}$ dolomite in lower the Cretaceous Erlian Basin, northern China (Yang et al. 2020). Moreover, the Md dolomite in the Erlian Basin have been described as white laminae, bands, and variably sized irregular breccias in a dark gray fine grained matrix (Fig. 4 B, Fig. 5 in Yang et al. 2020) that resembles the porphyritic-like texture in the Lucaogou Formation of the Shishugou Sag. Therefore, the comparison from several regions indicates that the phenocryst-like minerals in the eastern Junggar Basin most likely reflect the hydrothermal activities during the Lucaogou period.

Modern hydrothermal venting deposits or ancient SEDEX ores related to oceanic spreading centers usually have a negative $\delta \mathrm{Ce}$, likely owing to the oxidative scavenging of Ce by suspended $\delta-\mathrm{MnO}_{2}$ particles (De Carlo et al. 1998) and to a positive $\delta \mathrm{Eu}$ (Barrett et al. 1990; Mills and Elderfield 1995; Song et al. 1997; Subba Rao and Naqi 1997; McCarthy et al. 2005). However, the REE patterns of hydrothermal deposits in continental rift systems sometimes show no significant or positive $\delta \mathrm{Ce}$ and no significant or negative $\delta \mathrm{Eu}$ (Zheng et al. 2006; Li et al. 2011; Wen et al. 2013; Dekov et al. 2014). The chondrite-normalized REE patterns of the calcite, dolomite, analcime, and pyrite "phenocrysts" (Fig. 5) in the Lucaogou mudstones show a slightly positive $\delta \mathrm{Ce}$ and a clearly negative $\delta \mathrm{Eu}$, which are similar to those in the Permian 
Table 2 Major-element compositions of dolomite in Well Sh2, Shishugou Sag

\begin{tabular}{llllllllllllll}
\hline Mineral & $\begin{array}{l}\mathrm{Spot} \\
\text { number }\end{array}$ & $\begin{array}{l}\mathrm{CaO} \\
(\mathrm{wt} \%)\end{array}$ & $\begin{array}{l}\mathrm{TiO}_{2} \\
(\mathrm{wt} \%)\end{array}$ & $\begin{array}{l}\mathrm{P}_{2} \mathrm{O}_{5} \\
(\mathrm{wt} \%)\end{array}$ & $\begin{array}{l}\mathrm{SO}_{3} \\
(\mathrm{wt} \%)\end{array}$ & $\begin{array}{l}\mathrm{MgO} \\
(\mathrm{wt} \%)\end{array}$ & $\begin{array}{l}\mathrm{SiO}_{2} \\
(\mathrm{wt} \%)\end{array}$ & $\begin{array}{l}\mathrm{Al}_{2} \mathrm{O}_{3} \\
(\mathrm{wt} \%)\end{array}$ & $\begin{array}{l}\mathrm{MnO} \\
(\mathrm{wt} \%)\end{array}$ & $\begin{array}{l}\mathrm{TFeO} * \\
(\mathrm{wt} \%)\end{array}$ & $\begin{array}{l}\mathrm{Total} \\
(\mathrm{wt} \%)\end{array}$ & $\begin{array}{l}\mathrm{Mg} / \mathrm{Ca} \\
(\mathrm{wt} \% / \mathrm{wt} \%)\end{array}$ & $\begin{array}{l}(\mathrm{Mg}+\mathrm{Fe}) / \mathrm{Ca} \\
(\mathrm{wt} \% / \mathrm{wt} \%)\end{array}$ \\
\hline $\begin{array}{l}\text { Dolomite } \\
\mathrm{MgCa}\left(\mathrm{CO}_{3}\right)_{2}\end{array}$ & 001 & 27.4 & 0.01 & 0.03 & 0.08 & 13.48 & bdl & bdl & 0.55 & 8.40 & 50.0 & 0.42 & 0.75 \\
& 002 & 27.9 & 0.05 & 0.03 & bdl & 11.76 & bdl & bdl & 0.25 & 9.14 & 49.1 & 0.36 & 071 \\
& 003 & 27.7 & 0.06 & 0.05 & 0.03 & 12.42 & bdl & 0.02 & 0.30 & 9.56 & 50.1 & 0.38 & 0.75 \\
& 004 & 28.2 & 0.05 & 0.01 & 0.01 & 11.09 & bdl & bdl & 0.15 & 10.73 & 50.2 & 0.33 & 0.74 \\
& 005 & 28.2 & 0.03 & bdl & bdl & 12.06 & bdl & 0.03 & 0.24 & 9.73 & 50.3 & 0.36 & 0.74 \\
& 006 & 27.2 & bdl & 0.08 & 0.03 & 14.78 & bdl & 0.03 & 0.34 & 7.27 & 49.7 & 0.46 & 0.75 \\
& 007 & 26.6 & 0.03 & 0.03 & 0.05 & 11.87 & bdl & bdl & 0.19 & 11.09 & 49.9 & 0.38 & 0.83 \\
& 008 & 27.6 & 0.09 & bdl & bdl & 11.75 & bdl & bdl & 0.23 & 10.83 & 50.5 & 0.36 & 0.79 \\
& 009 & 27.9 & 0.12 & bdl & 0.06 & 12.14 & bdl & bdl & 0.13 & 10.56 & 50.9 & 0.37 & 0.78 \\
\hline
\end{tabular}

The testing spots 001 to 003 are labeled in Fig. 4 e

Abbreviations as in Table 1

hydrothermal analcime-dolomite-bearing deposits in the Lucaogou mudstones in Santanghu Basin, northwestern China ( $\mathrm{Li}$ et al. 2011), in the Cretaceous hydrothermal dolostones in the Qingxi Sag, Jiuquan Basin, western China (Wen et al. 2013), and in the hydrothermal dolomite in the lower Cretaceous Erlian Basin (Fig. 5 b, Yang et al. 2020). Moreover, the positive $\delta \mathrm{Ce}$, negative $\delta \mathrm{Eu}$, and slight HREE enrichment in the Lucaogou "phenocrysts" are similar to those of the aerobic, alkaline, and carbonate-rich waters in Lake Van, Turkey (Möller and Bau 1993), and the positive $\delta \mathrm{Ce}$ is similar to that found in the carbonate chimneys and lake water in the hyperalkaline and salty Lake Abhé, Afar Rift, East African system (Fig. 5 a, Dekov et al. 2014). However, such $\mathrm{Ce}$ and $\mathrm{Eu}$ anomalies reported here differ significantly from those in the hydrothermal carbonate deposits in Lake Tanganyika, East Africa, which feature a large negative $\delta \mathrm{Ce}$ and a slightly positive $\delta \mathrm{Eu}$ (Barrat et al. 2000). The different $\delta \mathrm{Ce}$ and $\delta \mathrm{Eu}$ values in these continental hydrothermal deposits may represent different redox and thermochemical states of the sedimentary environment, as previously indicated by Sverjensky (1984) and German and Elderfield (1990).

The $\mathrm{Ce}$ and $\mathrm{Eu}$ in the REEs can behave anomalously under certain redox conditions owing to the valence transition from the trivalent state to $\mathrm{Ce}^{4+}$ and $\mathrm{Eu}^{2+}$. $\mathrm{Ce}^{3+}$ is soluble in both anoxic and suboxic conditions and $\mathrm{Ce}$ becomes insoluble in seawater at low temperatures when oxidized to $\mathrm{Ce}^{4+}$, and therefore, it is removed from the REEs to produce a negative anomaly $(\delta \mathrm{Ce}<1$; German and Elderfield 1990). Because of its capacity to preserve the records of primary deposition even when subjected to multiple diagenetic alteration events (Liu et al. 2019), the $\delta \mathrm{Ce}$ method has been applied to ancient shallow marine carbonates to explore redox states over geological history (Elderfield and Greaves 1982; Kamber and Webb 2001; Sarangi et al. 2017). In the study area, the $\delta$ Ce in the Lucaogou phenocryst-like calcite ranges from 0.84 to 1.40 , with only 1 of the 19 values being <1 (Table 5); additionally, this might reflect anoxic conditions during crystallization. Similarly, the $\delta \mathrm{Ce}$ in the phenocryst-like dolomite, analcime, and pyrite in the Shishugou Sag is $0.98-1.07,0.76-1.02$, and $0.83-1.66$, respectively, which possibly represents suboxic to anoxic conditions during the formations of these minerals.

Divalent $\mathrm{Eu}$ is considered to be stable and is predominant at temperatures greater than approximately $250^{\circ} \mathrm{C}$. However, at low temperatures similar to the earth's surface conditions, the aqueous geochemistry of Eu would be dominated by trivalent $\mathrm{Eu}$ unless it occurs in extremely reducing alkaline solutions (Sverjensky 1984). During the hydrothermal alteration between the oceanic crust and the hydrothermal fluid in midoceanic ridge systems, the Eu released to the aqueous phase is expected to be converted to $\mathrm{Eu}^{2+}$ and related complexes (Sverjensky 1984); therefore, a positive anomaly is produced in hydrothermal minerals in equilibrium with an aqueous phase. This suggestion is supported by certain hydrothermal vent fluids and deposits reported in previous literature in midoceanic ridges and in the East African Rift system (Klinkhammer et al. 1983; Mills and Elderfield 1995; Barrat et al. 2000; Dekov et al. 2014). However, the chondritenormalized REE patterns in the Lucaogou phenocryst-like minerals show a distinctly negative anomaly in both the Jimusar and Shishugou sags (Fig. 5 a, b). Several factors can explain this result as follows: (1) Because the slightly positive $\delta \mathrm{Ce}$ indicates suboxic to anoxic conditions for mineral precipitation, the negative $\delta \mathrm{Eu}$ could indicate that the coarse calcite in the Jimusar Sag and the assemblages of dolomite, analcime, and pyrite in the Shishugou Sag were formed at temperatures at which the Eu was stabilized in the trivalent state. (2) Olivarez and Owen (1991) suggested that the $\delta \mathrm{Eu}$ in hydrothermal sediments decreases and becomes more "seawater- 
Table 3 Major-element compositions (in wt\%) of analcime in Well Sh2, Shishugou Sag

\begin{tabular}{llllllllllllll}
\hline Mineral & $\begin{array}{l}\text { Spot } \\
\text { number }\end{array}$ & $\mathrm{K}_{2} \mathrm{O}$ & $\mathrm{CaO}$ & $\mathrm{TiO}_{2}$ & $\mathrm{Na}_{2} \mathrm{O}$ & $\mathrm{Al}_{2} \mathrm{O}_{3}$ & $\mathrm{MgO}$ & $\mathrm{SiO}_{2}$ & $\mathrm{TFeO}^{*}$ & $\mathrm{MnO}^{2}$ & $\mathrm{Cr}_{2} \mathrm{O}_{3}$ & $\mathrm{Total}$ \\
\hline Analcime & 001 & $\mathrm{bdl}$ & 0.08 & bdl & 11.52 & 20.3 & bdl & 57.8 & 0.13 & bdl & 0.01 & 89.8 \\
$\mathrm{Na}\left(\mathrm{AlSi}_{2} \mathrm{O}_{6}\right)$ & 002 & $\mathrm{bdl}$ & 0.01 & 0.05 & 11.43 & 19.47 & 0.01 & 58.1 & 0.08 & bdl & 0.02 & 89.2 \\
$\cdot \mathrm{H}_{2} \mathrm{O}$ & 003 & 0.03 & 0.03 & 0.04 & 12.09 & 19.85 & bdl & 58.3 & 0.08 & bdl & bdl & 90.4 \\
& 004 & bdl & bdl & 0.03 & 12.39 & 20.5 & bdl & 56.6 & 0.15 & bdl & bdl & 89.7 \\
& 005 & bdl & bdl & bdl & 12.13 & 20.4 & bdl & 57.5 & 0.20 & 0.04 & 0.03 & 90.3 \\
& 006 & bdl & 0.02 & bdl & 12.19 & 20.5 & bdl & 56.9 & 0.17 & bdl & bdl & 89.8 \\
& 007 & 0.03 & 0.04 & 0.03 & 13.06 & 21.4 & bdl & 56.9 & 0.15 & bdl & 0.05 & 91.7 \\
& 008 & 0.05 & 0.03 & 0.03 & 11.50 & 20.3 & bdl & 57.5 & 0.27 & 0.02 & 0.03 & 89.7 \\
& 009 & 0.04 & 0.06 & bdl & 11.52 & 20.3 & bdl & 57.1 & 0.30 & 0.02 & 0.01 & 89.4 \\
& 010 & 0.02 & 0.04 & 0.05 & 11.97 & 20.7 & bdl & 57.9 & 0.36 & 0.02 & bdl & 91.1 \\
& 011 & 0.04 & 0.03 & 0.01 & 11.65 & 20.3 & bdl & 58.5 & 0.44 & bdl & bdl & 91.0 \\
& 012 & 0.03 & 0.05 & 0.04 & 12.59 & 21.0 & bdl & 57.7 & 0.44 & 0.08 & 0.05 & 92.0 \\
\hline
\end{tabular}

The testing spots 006 and 007 are labeled in Fig. $4 \mathrm{f}$

Abbreviations as in Table 1

like" with distance from the ridge axis. Therefore, the negative $\delta \mathrm{Eu}$ in the Lucaogou minerals likely indicate an off-axis site from the center of the continental normal fault system where the temperature of the hydrothermal fluid was less than $250{ }^{\circ} \mathrm{C}$. Moreover, the NASC-normalized REEs show flat patterns and a very slight $\delta \mathrm{Eu}$ (Fig. $5 \mathrm{c}, \mathrm{d}$ ), which indicates that these phenocryst-like minerals could have inherited the properties of lake water or normal sediments. (3) The chondrite-normalized $\mathrm{Ba} / \mathrm{La}$ ratios in the Jimusar calcite are high and fall in the $\mathrm{BO}$ zone in the $\mathrm{Ba} / \mathrm{La}-\mathrm{La} / \mathrm{Sm}$ graph (Fig. 6; Othman et al. 1989). These results are consistent with the $\delta \mathrm{Eu}$ and indicate that the calcite could have partly originated from the underlying biogenetic sediment. Moreover, the chondrite-normalized $\mathrm{Ba} / \mathrm{La}$ ratios in the Shishugou dolomite, analcime, and pyrite fall in the zones of MORB and PHC, which are the same as that of the upper Carboniferous basalt in the Junggar Basin and are close to Mixing Curve B, indicating a source from volcanic and clastic rocks beneath the Shishugou Sag (Fig. 6; Othman et al. 1989).

The primitive mantle-normalized trace element patterns show high concentrations of $\mathrm{Ba}, \mathrm{U}$, and $\mathrm{Sr}$ in the calcite and dolomite (ESM; Fig. S2 a, b). The Sr content in the calcite and dolomite "phenocrysts" fluctuates greatly from 634 to $3005 \mathrm{ppm}$ and from 1001 to $1528 \mathrm{ppm}$, respectively (Table 5), which is higher than those in the Permian well preserved biogenic brachiopod shells, which is at $245-$ 1585 ppm (Korte et al. 2006). The Sr anomalies, defined as $\mathrm{Sr} / \mathrm{Sr}^{*}=2 \mathrm{Sr}_{\mathrm{N}} /\left(\mathrm{Ce}_{\mathrm{N}}+\mathrm{Pr}_{\mathrm{N}}\right)$ with $\mathrm{C} 1$ normalizing data from Sun

Table 4 Major-element compositions (in wt\%) of pyrite in Well Sh2, Shishugou Sag

\begin{tabular}{|c|c|c|c|c|c|c|c|c|c|c|c|c|}
\hline Mineral & $\begin{array}{l}\text { Spot } \\
\text { number }\end{array}$ & $\mathrm{Fe}$ & S & $\mathrm{Ni}$ & $\mathrm{Au}$ & $\mathrm{Pb}$ & $\mathrm{Ag}$ & As & $\mathrm{Zn}$ & $\mathrm{Cu}$ & $\mathrm{Co}$ & Total \\
\hline \multirow{10}{*}{$\begin{array}{l}\text { Pyrite } \\
/ \mathrm{FeS}_{2}\end{array}$} & 001 & 46.1 & 53.4 & bdl & 0.06 & bdl & bdl & 0.09 & 0.06 & 0.01 & 0.03 & 99.8 \\
\hline & 002 & 46.4 & 53.6 & bdl & bdl & 0.10 & bdl & 0.03 & bdl & 0.01 & 0.14 & 100.3 \\
\hline & 003 & 46.5 & 53.5 & 0.05 & 0.01 & bdl & 0.03 & 0.02 & bdl & bdl & 0.10 & 100.2 \\
\hline & 004 & 46.6 & 53.5 & bdl & 0.08 & bdl & 0.07 & 0.04 & bdl & bdl & 0.06 & 100.4 \\
\hline & 005 & 46.0 & 54.0 & 0.03 & 0.10 & bdl & bdl & 0.08 & 0.07 & bdl & 0.05 & 100.3 \\
\hline & 006 & 45.7 & 53.2 & 0.01 & 0.25 & bdl & 0.03 & 0.08 & 0.06 & 0.07 & 0.04 & 99.4 \\
\hline & 007 & 46.8 & 54.3 & bdl & bdl & bdl & 0.07 & 0.05 & bdl & bdl & 0.06 & 101.3 \\
\hline & 008 & 45.9 & 53.1 & 0.05 & 0.14 & bdl & bdl & 0.03 & bdl & bdl & 0.07 & 99.3 \\
\hline & 009 & 46.6 & 53.0 & bdl & 0.04 & bdl & bdl & 0.20 & bdl & 0.06 & 0.06 & 100.0 \\
\hline & 010 & 46.2 & 53.8 & bdl & bdl & bdl & 0.03 & 0.12 & bdl & bdl & 0.09 & 100.2 \\
\hline
\end{tabular}

Abbreviations as in Table 1 


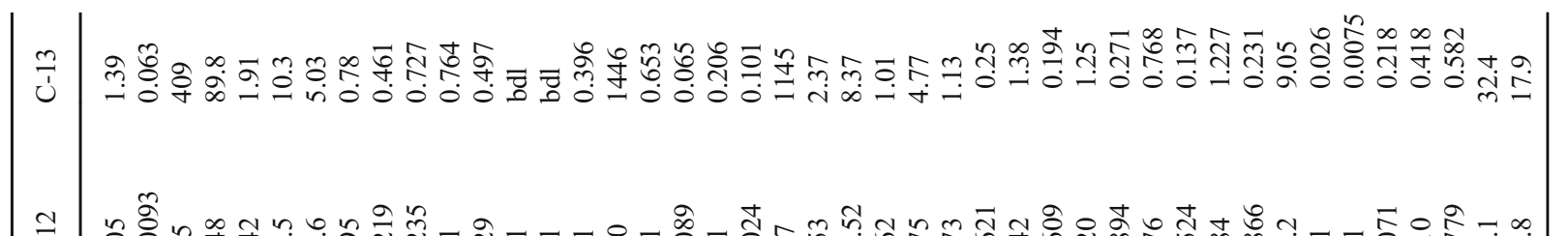

J

J J

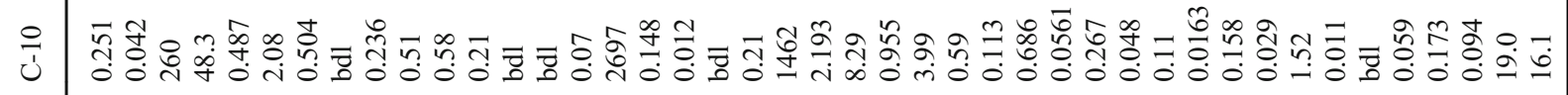

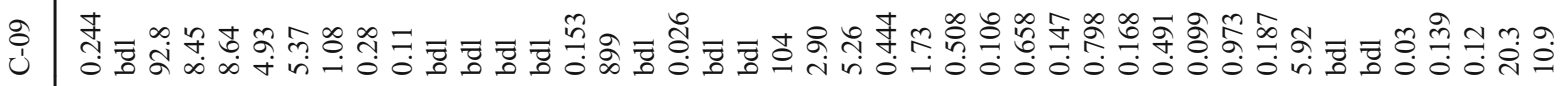

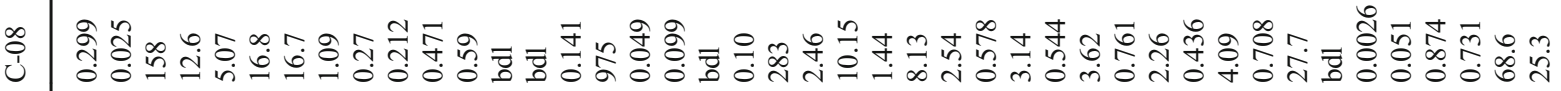

U

U

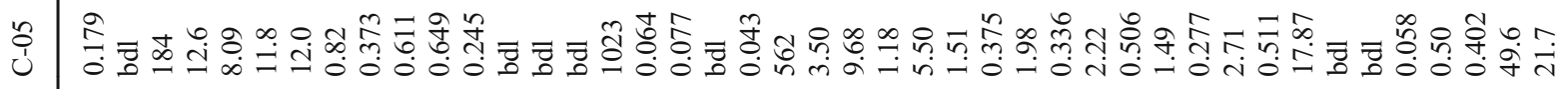

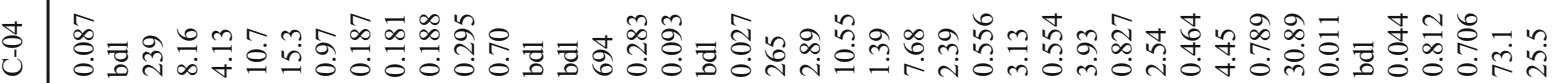

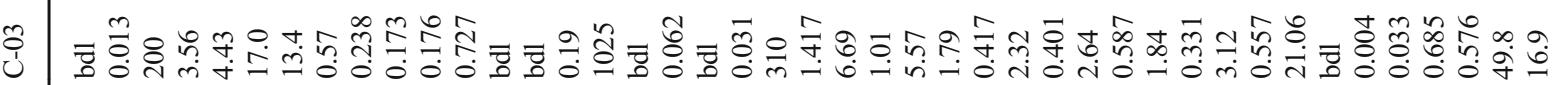
岁

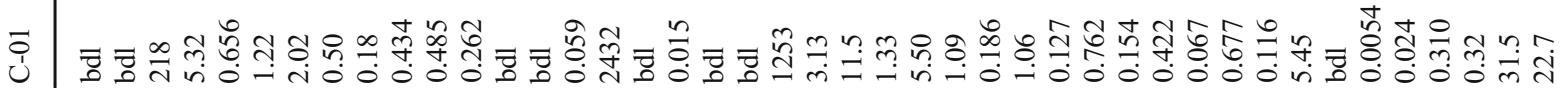

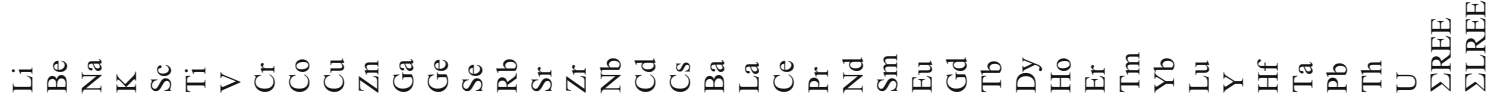




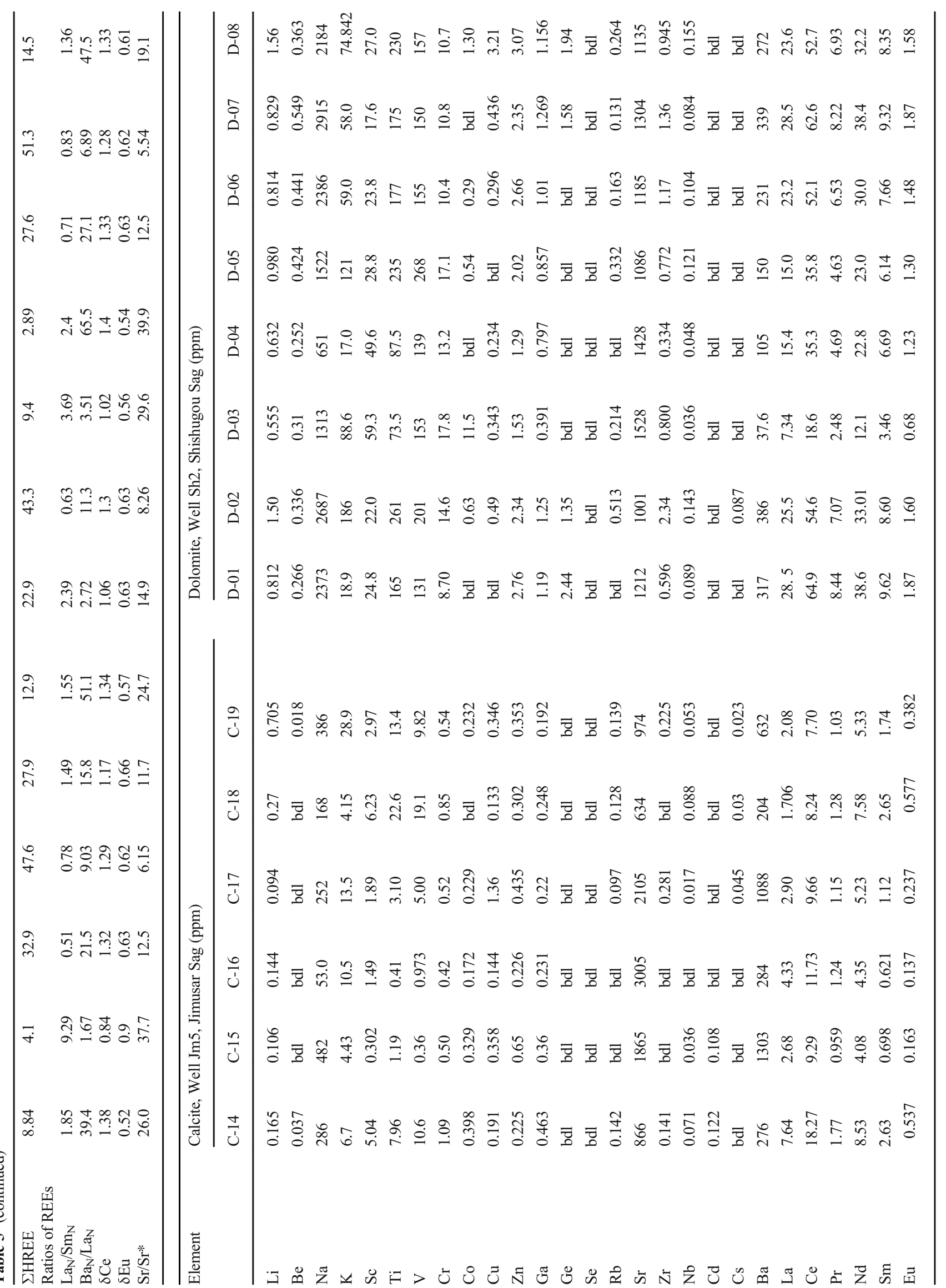




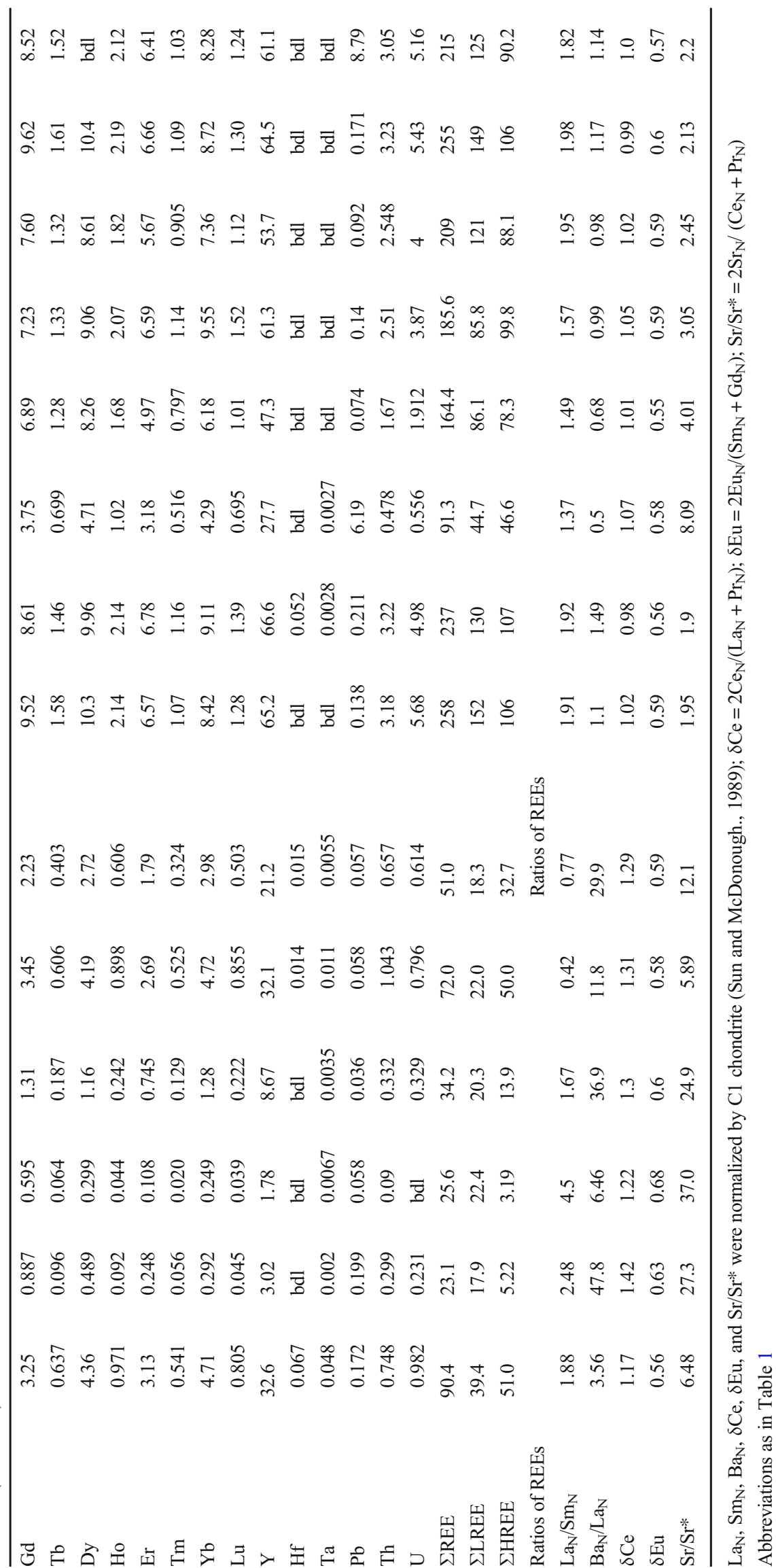



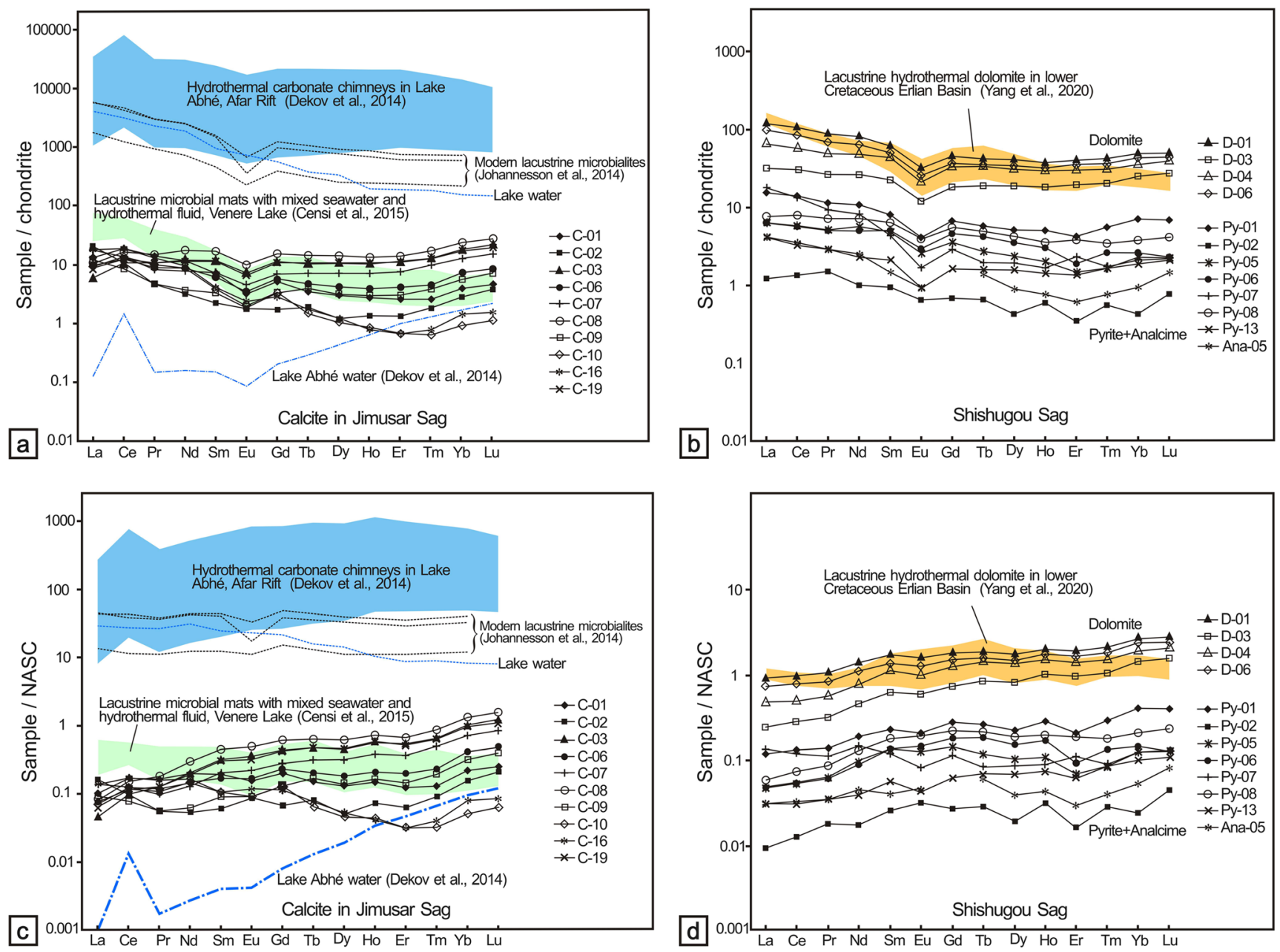

Fig. 5 REE patterns of calcite in Jimusar Sag, and dolomite-pyriteanalcime in Shishugou Sag. (a) Chondrite-normalized (Sun and McDonough 1989) REE patterns of calcite in Jimusar Sag, hydrothermal carbonate chimneys and lake water in Lake Abhé, Afar Rift (Data from Table 1, Dekov et al. 2014), lacustrine calcite dominant microbialites and lake water in Cuatro Ciénegas Bolson, Coahuila, México (Data from Table 14.2, Johannesson et al. 2014), and carbonate-rich microbial mat formed in mixed lake water, seawater, and hydrothermal fluid in Venere Lake, Pantelleria Island (Data from MM-1, MM-2, MM-3 in Supplementary materials, Censi et al. 2015). (b) Chondrite-normalized REE patterns of dolomite, pyrite, and analcime in

and McDonough (1989), reflect the fractions from Ce-Pr (Niu and $\mathrm{O}^{\prime}$ Hara 2009). In the research area, all the $\mathrm{Sr} / \mathrm{Sr}^{*}$ in the carbonate "phenocrysts," particularly those in the Jimusar calcite, are considerably higher than 1 , with the values of 5.54 39.9 and 1.9-8.09 in the Jimusar calcite and the Shishugou dolomite, respectively (Table 5). The strongly positive $\mathrm{Sr}$ anomalies indicate a significant enrichment of $\mathrm{Sr}$ in comparison with $\mathrm{Ce}$ and $\mathrm{Pr}$. Sr is believed to be expelled easily from carbonate sediments during diagenetic recrystallization (Parekh et al. 1977; Veizer 1989). However, no distinct lithological or mineralogical texture of strong recrystallization or diagenetic alteration was responsible for the high $\mathrm{Sr}$ enrichment in these calcite and dolomite "phenocrysts" during the
Shishugou Sag, and lacustrine hydrothermal dolomite in lower Cretaceous, Erlian Basin (Data from Md dolomite in Table 2, Yang et al. 2020). (c) NASC-normalized (Gromet et al. 1984) REE patterns of calcite in Jimusar Sag, hydrothermal carbonate chimneys and lake water in Lake Abhé, Afar Rift, lacustrine calcite dominant microbialites and lake water in Cuatro Ciénegas Bolson, Coahuila, México, and carbonate-rich microbial mat formed in mixed lake water, seawater, and hydrothermal fluid in Venere Lake, Pantelleria Island. (d) NASCnormalized REE patterns of dolomite, pyrite, and analcime in Shishugou Sag, and lacustrine hydrothermal dolomite in lower Cretaceous, Erlian Basin

burial process. Thus, the high $\mathrm{Sr}$ concentrations and highly positive $\mathrm{Sr}$ anomalies could be attributed to an extra source of Sr, which participated in the precipitation of Lucaogou phenocryst-like calcite and dolomite.

\section{Isotopic evidence for mineral formation}

Although seawater and lake water are the most likely sources for the formation of hydrothermal minerals, they are also marked by contributions from other sources such as endmember hydrothermal fluid, fluid from rock-water interactions, or magmatic water (Giggenbach 1992; Mills and Elderfield 1995; McCarthy et al. 2005; Dekov et al. 2014). 


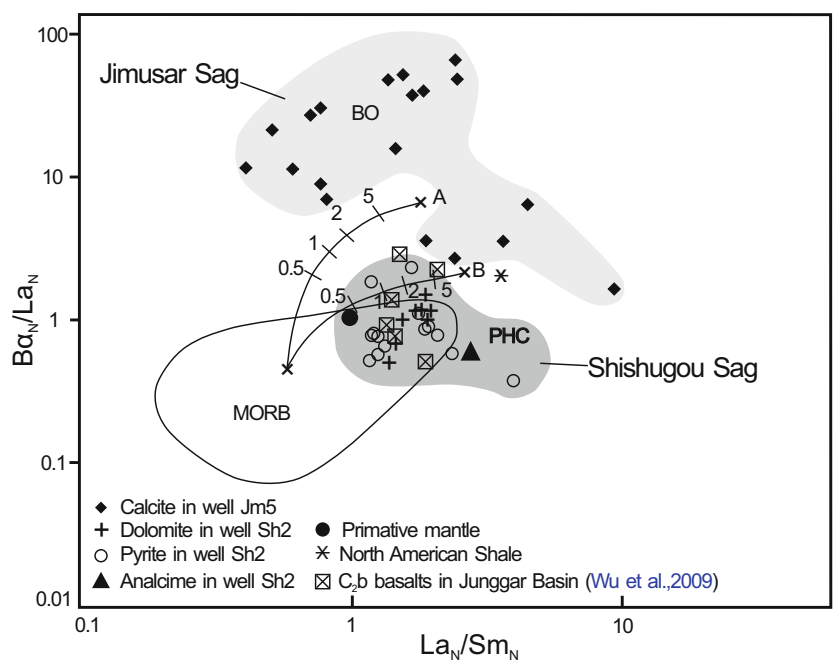

Fig. $6 \mathrm{Ba}_{N} / \mathrm{La}_{\mathrm{N}}-\mathrm{La}_{\mathrm{N}} / \mathrm{Sm}_{\mathrm{N}}$ in calcite, dolomite, analcime, and pyrite. The background figure is cited from Fig. 8 in Othman et al. (1989). MORB: Mid-Ocean Ridge Basalt; BO: Biogenic Sediment zone; Curve A: Mixing curve between a hypothetical mantle composition and percent high $\mathrm{Ba} / \mathrm{La}$ Pacific biogenic sediment (numbers); Curve B: Mixing curve between a hypothetical mantle composition and percent average composition for all sediments (numbers)

The mixing of fluids from different sources can directly affect the isotopic composition and the physical and chemical properties of hydrothermal fluids and relevant sediments (McCarthy et al. 2005). Mixed fluids in varying proportions can sometimes produce a wide range of isotopic variations in mineral precipitation. Mills and Elderfield (1995) attributed the ${ }^{87} \mathrm{Sr} /{ }^{86} \mathrm{Sr}$ isotope ratios of $0.705136-0.706669$ in TransAtlantic Geotraverse (TAG) anhydrites, located at $26^{\circ} \mathrm{N}$ on the Mid-Atlantic Ridge, to the mixtures of seawater and hydrothermal fluid, with ${ }^{87} \mathrm{Sr} /{ }^{86} \mathrm{Sr}$ compositions of 0.70916 and 0.70319 , respectively. Yang et al. (2018) reported ${ }^{87} \mathrm{Sr} /{ }^{86} \mathrm{Sr}$ isotope ratios ranging from 0.707878 to 0.712426 in bedded hydrothermal barite in Mesoproterozoic Jingtieshan deposits in the North Qilian Mountains, which reflect the results of submarine hydrothermal solutions mixed with seawater. In the East African Rift system, low ${ }^{87} \mathrm{Sr} /{ }^{86} \mathrm{Sr}$ isotope ratios of 0.704148 to 0.705879 in the carbonate chimneys of Lake Abhé, Afar Rift, represent a mixture of spring fluid and lake water, with ${ }^{87} \mathrm{Sr} /{ }^{86} \mathrm{Sr}=0.703809$ and 0.706565 , respectively (Dekov et al. 2014). However, the ${ }^{87} \mathrm{Sr} /{ }^{86} \mathrm{Sr}$ isotope ratios in the hydrothermal aragonite chimneys of Lake Tanganyika, which belong to the same East Africa Rift system, are $0.72183-0.72495$ and are much higher than those of the Lake Abhé carbonates. The relatively high Sr isotopes can be attributed to the mixing of fluids between lake water and hydrothermal fluid as well. These fluctuations of ${ }^{87} \mathrm{Sr} /{ }^{86} \mathrm{Sr}$ ratios in hydrothermal deposits indicate that ambient water and hydrothermal fluids both play a vital role in the formation of hydrothermal minerals.

The ${ }^{87} \mathrm{Sr} /{ }^{86} \mathrm{Sr}$ ratios in the phenocryst-like calcite in the Jimusar Sag vary between 0.705002 and 0.705776 , which are considerably less than the minimum value of the ${ }^{87} \mathrm{Sr} /{ }^{86} \mathrm{Sr}$ ratios in Permian seawater, reported as 0.70685 (Fig. 7; Korte et al. 2006) and 0.706914 (Kani et al. 2008), as well as less than the values of Pennsylvanian seawater, reported at $>0.7070$ (Veizer 1989). The regional extension status of the eastern Junggar Basin lasted from $330 \mathrm{Ma}$ to $265 \mathrm{Ma}$, which is also known as the continental rift stage ( $\mathrm{Li}$ et al. 1992) or post-collisional plutonism (Han et al. 2006). During the Lucaogou period, volcanic activities decreased gradually, although sublacustrine hydrothermal activities were still frequent in and around the study area (Liu et al. 2012; Jiao et al. 2018). Although the relatively high $\mathrm{Ba}_{N} / \mathrm{La}_{\mathrm{N}}$ ratios in the calcite indicate a biogenic source (Fig. 6) that likely originated from the leaching of underlying late Carboniferous limestones, the low Sr isotopes, which partly overlap the range of $\mathrm{Sr}$ ratios of late Carboniferous basalts and andesites (ESM; Fig. S3), and the significantly positive $\mathrm{Sr}$ anomalies, both demonstrate that magmatic water from the deep magma chamber may be another source for the formation of the phenocryst-like calcite in the Jimusar Sag.

Regarding the phenocryst-like mineral assemblages in the Shishugou Sag, the ${ }^{87} \mathrm{Sr} /{ }^{86} \mathrm{Sr}$ ratios of dolomite overlap those of calcite and $\mathrm{C}_{2} \mathrm{~b}$ volcanic rocks (ESM; Fig. S3), and the spots of $\mathrm{Ba} / \mathrm{La}-\mathrm{La} / \mathrm{Sm}$ of the dolomite, analcime, and pyrite all fall into the same zone as those of the $\mathrm{C}_{2} \mathrm{~b}$ basalts and are close to the Mixing Curve B (Fig. 6). These isotopic and geochemical features could explain the hydrothermal fluid as a mixture of both lake water and underlying $\mathrm{C}_{2} \mathrm{~b}$ volcanic and detrital rocks such that cold lake water flowed down along the fractures, became heated and interacted with the underlying volcanic and detrital rocks, and returned to the bottom of the lake in the Shishugou Sag.

Driven by associated water-rock interactions between seawater and underlying basalts, the $\delta^{34} \mathrm{~S}$ of hydrothermal sulfide is approximately $0-6 \%$ in sediment-barren mid-oceanic ridge regions (Woodruff and Shanks III 1988; Seal II 2006; Zeng et al. 2017). However, the changes in $S$ isotopes vary widely from those documented in other sites such as along the MidAtlantic Ridge, back arc, arc settings, and sediment-host systems (Fig. 11 in Shanks III 2001) as a result of thermochemical reductions of seawater sulfate, the involvement of terrestrial sediments, bacterial sulfate reductions, fluid $\mathrm{pH}$, and other factors (Shanks III 2001; Seal II 2006; Peters et al. 2010; Lee et al. 2018). The bulk $\mathrm{S}$ isotope of Galapagos ridge basalts is $0.3 \pm 0.5 \%$, with an average fraction factor of $+7.4 \pm 1.6 \%$ o between the sulfate and sulfide (Sakai et al. 1984). Seawater sulfate has a $\delta^{34} \mathrm{~S}$ value of $+21 \%$ (Rees et al. 1978). In contrast, bacterial sulfate reduction is believed to be responsible for the strongly depleted $\delta^{34} \mathrm{~S}$ values of up to $-30 \%$ (Shanks III 2001). The variation in $\mathrm{S}$ isotopes in thermal fluids on land might reflect the complexity of the $\mathrm{S}$ source, isotopic fractionation in different temperature systems, water-rock interactions, and redox reactions in submarine hydrothermal systems. Gunnarsson-Robin et al. (2017) reported multiple S isotope 
Table 6 In situ analytical results of the ${ }^{87} \mathrm{Sr} /{ }^{86} \mathrm{Sr}$ ratios of calcite and dolomite in the Lucaogou Formation

\begin{tabular}{|c|c|c|c|c|c|c|c|c|c|}
\hline $\begin{array}{l}\text { Spot } \\
\text { number }\end{array}$ & Mineral & Location & ${ }^{87} \mathrm{Sr} /{ }^{86} \mathrm{Sr}$ & $2 \sigma$ & $\begin{array}{l}\text { Spot } \\
\text { number }\end{array}$ & Mineral & Location & ${ }^{87} \mathrm{Sr} /{ }^{86} \mathrm{Sr}$ & $2 \sigma$ \\
\hline NO-001 & calcite & Well Jm5, Jimusar Sag & 0.705465 & 0.000040 & NO-027 & dolomite & Well Sh2, Shishugou Sag & 0.705972 & 0.000033 \\
\hline NO-002 & & & 0.705488 & 0.000034 & NO-028 & & & 0.705959 & 0.000040 \\
\hline NO-003 & & & 0.705283 & 0.000029 & NO-029 & & & 0.705968 & 0.000037 \\
\hline NO-004 & & & 0.705363 & 0.000035 & NO-030 & & & 0.705751 & 0.000032 \\
\hline NO-005 & & & 0.705498 & 0.000052 & NO-031 & & & 0.705321 & 0.000014 \\
\hline NO-006 & & & 0.705422 & 0.000062 & NO-032 & & & 0.705696 & 0.000049 \\
\hline NO-007 & & & 0.705349 & 0.000022 & NO-033 & & & 0.705916 & 0.000028 \\
\hline NO-008 & & & 0.705735 & 0.000046 & NO-034 & & & 0.705750 & 0.000014 \\
\hline NO-009 & & & 0.705230 & 0.000039 & NO-035 & & & 0.705841 & 0.000027 \\
\hline NO-010 & & & 0.705065 & 0.000047 & NO-036 & & & 0.705845 & 0.000031 \\
\hline NO-011 & & & 0.705397 & 0.000035 & NO-037 & & & 0.705854 & 0.000028 \\
\hline NO-012 & & & 0.705386 & 0.000057 & NO-038 & & & 0.705794 & 0.000026 \\
\hline NO-013 & & & 0.705425 & 0.000033 & NO-039 & & & 0.705834 & 0.000031 \\
\hline NO-014 & & & 0.705266 & 0.000016 & NO-040 & & & 0.705765 & 0.000026 \\
\hline NO-015 & & & 0.705343 & 0.000022 & NO-041 & & & 0.705608 & 0.000025 \\
\hline NO-016 & & & 0.705072 & 0.000021 & NO-042 & & & 0.705769 & 0.000030 \\
\hline NO-017 & & & 0.705307 & 0.000022 & NO-043 & & & 0.705772 & 0.000038 \\
\hline NO-018 & & & 0.705368 & 0.000030 & NO-044 & & & 0.705912 & 0.000038 \\
\hline NO-019 & & & 0.705518 & 0.000034 & & & & & \\
\hline NO-020 & & & 0.705206 & 0.000020 & & & & & \\
\hline NO-021 & & & 0.705002 & 0.000020 & & & & & \\
\hline NO-022 & & & 0.705152 & 0.000027 & & & & & \\
\hline NO-023 & & & 0.705329 & 0.000034 & & & & & \\
\hline NO-024 & & & 0.705446 & 0.000039 & & & & & \\
\hline NO-025 & & & 0.705490 & 0.000046 & & & & & \\
\hline NO-026 & & & 0.705776 & 0.000036 & & & & & \\
\hline
\end{tabular}

compositions in Icelandic geothermal fluids with $\delta^{34} \mathrm{~S}$ for $\Sigma \mathrm{S}^{-\mathrm{II}}, \mathrm{SO}_{4}$, and $\mathrm{H}_{2} \mathrm{~S}$ (gas) at values of $-11.6-10.5 \%$ o, -1.0 $24.9 \%$, and $-2.6-5.9 \%$, respectively, which confirms the mixed S sources of MORB leaching and the reduction of seawater sulfate. In the Shishugou Sag, the $\delta^{34} \mathrm{~S}$ values of the phenocryst-like pyrite fluctuates in a narrow range between $10.8 \pm 0.14 \%$ and $12.3 \pm 0.16 \%$, with an average of $11.6 \%$, which partly overlap with the $\delta^{34} \mathrm{~S}$ values in sediment-host ridges (Fig. 8). Because the bacterial sulfate reduction tends to produce depleted $\mathrm{S}$ isotopes and large isotopic fractionation in sulfides (Habicht and Canfield 2001), the positive $\delta^{34} \mathrm{~S}$ values in the Lucaogou pyrite indicate mixed sources of S from the leaching of underlying basalts and sediments and the abiotic thermochemical sulfate reduction of lake water or organic matter (Goldstein and Aizenshtat 1994; Seal II 2006). Moreover, the variation in S isotopes in the Lucaogou pyrite might reflect the different proportions of hydrothermal sources in the mixed hydrothermal fluid. Ohmoto and Lasaga (1982) found that the sulfate-sulfide equilibrium could not be attained during the co-precipitation of sulfate and sulfide minerals at $\mathrm{T} \leq 350{ }^{\circ} \mathrm{C}$ unless the $\mathrm{pH}$ was low. If the negative $\delta \mathrm{Eu}$ indicates the presence of hydrothermal fluid at temperatures of less than $250{ }^{\circ} \mathrm{C}$ before the precipitation of minerals, $\mathrm{S}$ isotope disequilibrium was likely

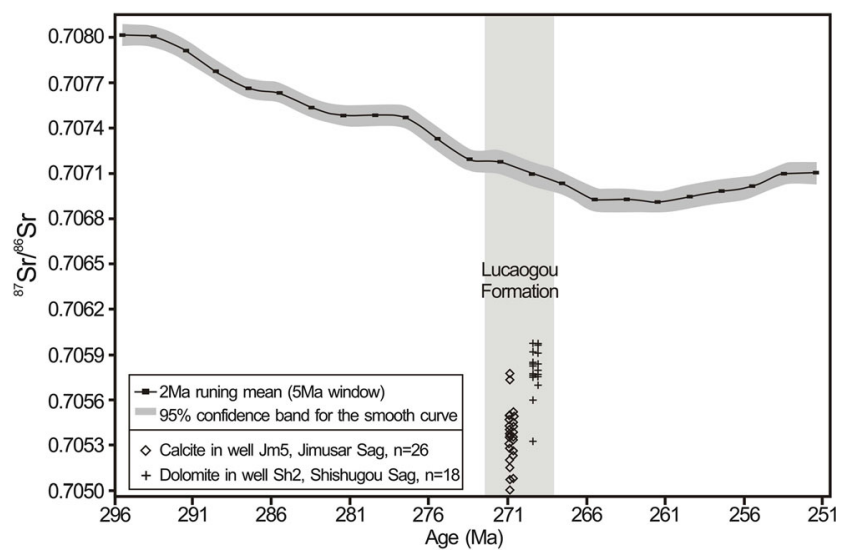

Fig. 7 In situ analytical results of ${ }^{87} \mathrm{Sr} /{ }^{86} \mathrm{Sr}$ ratios for calcite and dolomite in the Lucaogou Formation. Background graph of "Running ${ }^{87} \mathrm{Sr} /{ }^{86} \mathrm{Sr}$ mean for well-preserved Permian brachiopod shells" is cited from Fig. 5 of Korte et al. (2006). The position of the Lucaogou Formation in the Permian time scale is obtained from Yang et al. $(2007,2010)$ 


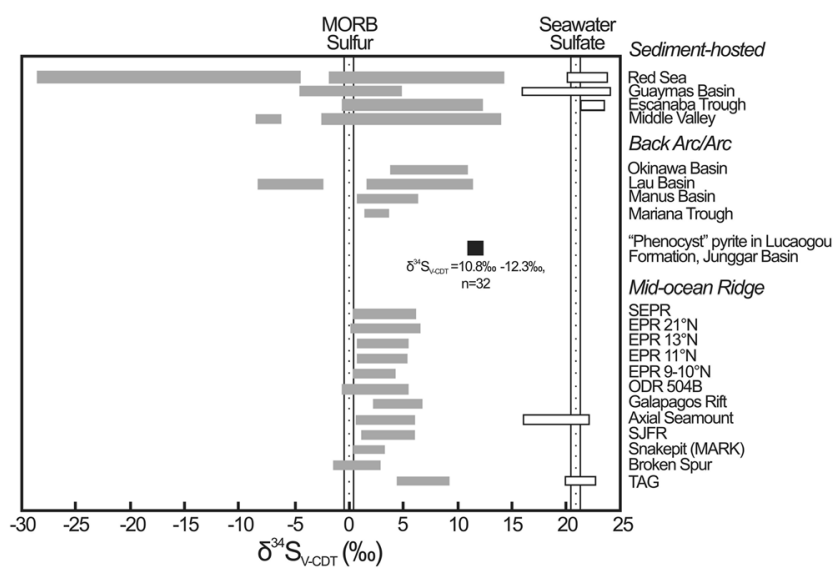

Fig. $8 \delta^{34} \mathrm{~S}_{\mathrm{V}-\mathrm{CDT}}$ of pyrite in the Permian Lucaogou Formation. Background graph of "Range of $\delta^{34} \mathrm{~S}$ for sulfide and sulfate minerals from modern seafloor hydrothermal system" is cited from Fig. 18 of Seal II (2006)

dominant during the formation of the Lucaogou pyrite in the Shishugou Sag. A simple two end-member mixing model was used to roughly evaluate the proportion of sulfur sources from the mixed isotopic compositions $\left(\delta^{34} \mathrm{~S}_{\text {mixture }}=\mathrm{X} \cdot \delta^{34} \mathrm{~S}_{\text {sulfate }}+\right.$ $(1-\mathrm{X}) \cdot \delta^{34} \mathrm{~S}_{\text {basalt }}$. When assuming $\delta^{34} \mathrm{~S}_{\text {sulfate }}=+21 \%$, based on the $\delta^{34} \mathrm{~S}$ values of seawater sulfate owing to a lake of relevant research; $\delta^{34} \mathrm{~S}_{\text {basalt }}=0 \%$, based on MORB; and $\delta^{34} \mathrm{~S}_{\text {mixture }}=+11.6 \%$, based on the average value of Lucaogou pyrite, the percentage of the $\mathrm{S}$ source from dissolved sulfate would be approximately $55 \%$ of the total sulfur isotope composition, with the remaining $45 \%$ possibly originated from underlying basaltic rocks.

Although further work is needed to explore the detailed processes of the hydrothermal activities responsible for the formation of phenocryst-like minerals in the Lucaogou Formation, as is more evidence for the potential fluid sources and their proportions in the Jimusar and Shishugou sags, the present results from the in situ $\mathrm{S}$ isotopes in pyrite are consistent with those from the in situ $\mathrm{Sr}$ isotopes of the carbonates and with geochemical features of REEs and their ratios. This indicates that the phenocryst-like calcite, dolomite, analcime, and pyrite in the Lucaogou Formation in the eastern Junggar Basin were precipitated from mixed hydrothermal fluids of various sources.

\section{Formation of the "porphyritic" texture in Lucaogou mudstones}

In addition to the geochemical evidence of the Lucaogou phenocryst-like mineral assemblages, the detailed microscopic features of the minerals exclude the "porphyritic" texture from diagenetic origin; instead, the calcite and dolomite-analcime-pyrite, and fine-grained sediments are more similar to the primary textural components as the "phenocryst" and "matrix" of the rock. Microscopic and back-scatter observations revealed that the coarse calcite assemblages in Well Jm5 and the analcime-dolomite-pyrite assemblages in Well Sh2 were distributed along or surrounded by compressed micro-laminae (Fig. 3 b, g; Fig. 4 a, b). This indicates that they formed very early, possibly during the syn-sedimentary period, or at least earlier than the early burial diagenesis of mechanic compaction in the surrounding fine-grained sediments.

The OM-CL imaging revealed that the calcite assemblages in Well Jm5 have two stages of luminescent textures: Stage I calcite with orange to dull orange luminescence zoning and non-luminescent cores (white arrows in Fig. 3 c-e), and Stage II calcite with diagenetic bright orange luminescence (white dotted arrows in Fig. $3 \mathrm{c}-\mathrm{e}$ ). $\mathrm{Mn}$ and $\mathrm{Fe}$ are widely believed to be the main activator and quencher, respectively, of visible CL in sedimentary carbonates (Fairchild 1983; Habermann et al. 1996; Budd et al. 2000). The bright orange luminescence of Stage II calcite indicates a diagenetic origin with the participation of Mn during burial. However, the oscillatory zonings of Stage I calcite indicate a primary texture of crystal growth and are similar to some extent to the zoned phenocrysts in volcanic rocks, which reflect the changes in the melt composition or magma mixing (Anderson Jr 1984; Watt et al. 1997; Churikova et al. 2013). Meanwhile, the incomplete outlines of calcite indicate that these crystals might have broken before being settled down into the sublacustrine sediments (Fig. $3 \mathrm{c}-$ f). Budd et al. (2000) suggested $100 \mathrm{ppm} \mathrm{Fe}$ as the minimum for the quenching of CL when $\mathrm{Mn}$ is below $200 \mathrm{ppm}$ and that $25 \mathrm{ppm} \mathrm{Mn}$ is necessary to initiate visible CL. Moreover, Hemming et al. (1989) proposed that calcite with more than approximately $100 \mathrm{ppm} \mathrm{Mn}$ will still luminesce even under Fe concentrations of up to $10,000 \mathrm{ppm}$. The EPMA major elemental analysis showed that most calcite cores have no detectable Mn (Table 1), which is consistent with their features of non-luminescence. However, the existence of both $\mathrm{Mn}$ and $\mathrm{Fe}$ at averages of $334 \mathrm{ppm}$ and $1184 \mathrm{ppm}$, respectively, in the zones of Stage I calcite explains the dull color in the OM-CL. The phenocryst-like dolomite was non-luminescent which is likely due to the quenching of extremely high Fe concentrations in Well Sh2 (Table 2).

In summary, the compressed surrounding laminae in the "matrix," the broken crystal forms, and the differences in luminescence between Stage I and Stage II calcite indicate that the primary origin of the calcite "phenocryst" is the release of early crystallized calcite from hydrothermal fluids rather than cavity-filling products in the burial diagenetic process.

\section{Conclusions}

The eastern Junggar area formed in the late stage of continental extension (rift) during the middle Permian period and was filled with lacustrine dominated sediments with numerous tectonic fractures connecting to the underlying formations. 
Along the fractures, lake water flowed down through the underlying rocks and was heated by and mixed with deep upwelling magmatic water. In this process, the rock and fluids interacted, which precipitated new minerals that were carried back to the lake floor with the mixed hydrothermal fluid. The diverse mineral assembles in the Jimusar and Shishugou sags, the geochemistry of the elements and elemental ratios, and their $\mathrm{Sr}$ and $\mathrm{S}$ isotopes reflect the complexity of hydrothermal fluid sources, such that they were controlled by the sedimenthost or organic matter-host environment and the underlying rock type. Unlike the SEDEX deposits or massive polymetallic ores formed in submarine hydrothermal fields, the understanding of the scientific and economic significance of ancient lacustrine hydrothermal activities remains limited. Therefore, further research is needed to explore the potential relationship between hydrothermal activity and the formation of hydrocarbon in ancient tectonic active basins. The phenocryst-like minerals and mineral assemblages found in the Lucaogou Formation could provide an insight into tracing the hydrothermal activities in ancient terrestrial successions.

Supplementary Information The online version contains supplementary material available at https://doi.org/10.1007/s00710-020-00726-8.

Acknowledgements We thank our colleagues Yang Wenqiang, Gong Huadong, Chen Lu, Chen Kaiyun, Bao Zhian, and Ran Yazhou in State Key Laboratory of Continental Dynamics for their generous help in conducting laboratory analyses. We are grateful to two anonymous reviewers, Supriya Lokhande, and editors Qiuli Li and Lutz Nasdala for the constructive comments. This work is supported by the projects of the National Natural Science Foundation of China (NSFC; Grants 41272115, 41272116, 41572086) and Xinjiang Oilfield Company of Petro China.

Open Access This article is licensed under a Creative Commons Attribution 4.0 International License, which permits use, sharing, adaptation, distribution and reproduction in any medium or format, as long as you give appropriate credit to the original author(s) and the source, provide a link to the Creative Commons licence, and indicate if changes were made. The images or other third party material in this article are included in the article's Creative Commons licence, unless indicated otherwise in a credit line to the material. If material is not included in the article's Creative Commons licence and your intended use is not permitted by statutory regulation or exceeds the permitted use, you will need to obtain permission directly from the copyright holder. To view a copy of this licence, visit http://creativecommons.org/licenses/by/4.0/.

\section{References}

Anderson AT Jr (1984) Probable relations between plagioclase zoning and magma dynamics, Fuego volcano, Guatemala. Am Mineral 69: 660-676

Baker ET, Resing JA, Haymon RM, Tunnicliffe V, Lavelle JW, Martinez F, Ferrini V, Walker SL, Nakamura K (2016) How many vent fields? New estimates of vent field populations on ocean ridges from precise mapping of hydrothermal discharge locations. Earth Planet Sc Lett 449:186-196

Baker ET (2017) Exploring the ocean for hydrothermal venting: new techniques, new discoveries, new insights. Ore Geol Rev 86:55-69

Bao Z, Chen L, Zong C, Yuan H, Chen K, Dai M (2017) Development of pressed sulfide powder tablets for in situ sulfur and lead isotope measurement using LA-MC-ICP-MS. Int J Mass Spectrom 421: $255-262$

Barrett TJ, Jarvis I, Jarvis KE (1990) Rare earth element geochemistry of massive sulfides-sulfates and gossans on the southern explorer ridge. Geology 18:583-586

Barrat JA, Boulègue J, Tiercelin JJ, Lesourd M (2000) Strontium isotopes and rare-earth element geochemistry of hydrothermal carbon deposits from Lake Tanganyika, East Africa. Geochim Cosmochim Ac 64:287-298

Budd D, Hammes U, Ward WB (2000) Cathodoluminescence in calcite cements: new insights on $\mathrm{Pb}$ and $\mathrm{Zn}$ sensitizing, $\mathrm{Mn}$ activation, and $\mathrm{Fe}$ quenching at low trace-element concentrations. J Sediment Res 70:217-226

Campbell KA (2006) Hydrocarbon seep and hydrothermal vent paleoenvironments and paleontology: past developments and future research directions. Palaeogeogr Palaeocl 232:362-407

Carroll AR, Liang Y, Graham SA, Xiao X, Hendrix MS, Chu J, McKnight CL (1990) Junggar basin, Northwest China: trapped late Paleozoic Ocean. Tectonophysics 181:1-14

Carroll AR (1998) Upper Permian lacustrine organic facies evolution, southern Junggar Basin, NW China. Org Geochem 28:649-667

Censi P, Cangemi M, Brusca L, Madonia P, Saiano F, Zuddas P (2015) The behavior of rare-earth elements, $\mathrm{Zr}$ and $\mathrm{Hf}$ during biologicallymediated deposition of silica-stromatolites and carbonate-rich microbial mats. Gondwana Res 27:209-215

Chen L, Chen K, Bao Z, Liang P, Sun T, Yuan H (2017) Preparation of standards for in situ sulfur isotope measurement in sulfides using femtosecond laser ablation MC-ICP-MS. J Anal Atom Spectrom 32: $107-116$

Chen L, Yuan H, Chen K, Bao Z, Zhu L, Liang P (2019) In situ sulfur isotope analysis by laser ablation MC-ICPMS and a case study of the Erlihe $\mathrm{Zn}-\mathrm{Pb}$ ore deposit, Qinling orogenic belt, Central China. J Asian Earth Sci 176:325-336

Churikova TG, Ivanov BV, Eichelberger J, Wörner G, Browne B, Zbekov P (2013) Major and trace element zoning in plagioclase from Kizimen volcano (Kamchatka): insights into magma chamber processes. J Volcanol Seismol 7:112-130

De Carlo EH, Wen X, Irving M (1998) The influence of redox reactions on the uptake of dissolved Ce by suspended Fe and Mn oxide particles. Aquat Geochem 3:357-389

Dekov VM, Egueh NM, Kamenov GK, Bayon G, Lalonde SV, Schmidt M, Liebetrau V, Munnik F, Fouquet Y, Tanimizu M, Awaleh MO, Guirreh I, Le Gall B (2014) Hydrothermal carbonate chimneys from a continental rift (Afar rift): mineralogy, geochemistry, and mode of formation. Chem Geol 387:87-100

Edmond FM (1981) Hydrothermal activity at mid-ocean ridge axes. Nature 129:87-88

Elderfield H, Greaves MJ (1982) The rare earth elements in seawater. Nature 296:214-218

Fairchild IJ (1983) Chemical controls of cathodoluminescence of natural dolomites and calcites: new data and review. Sedimentology 30: 579-583

Fallon EK, Petersen S, Brooker RA, Scott TB (2017) Oxidative dissolution of hydrothermal mixed-sulphide ore: an assessment of current knowledge in relation to seafloor massive sulphide mining. Ore Geol Rev 86:309-337

Fang Y, Wu C, Wang Y, Hou K, Guo Z (2019) Topographic evolution of the Tianshan Mountains and their relation to the Junggar and Turpan basins, Central Asia, from the Permian to the Neogene. Gondwana Res 75:47-67 
Fournier RO (1989) Geochemistry and dynamics of the Yellowstone National Park hydrothermal system. Annu Rev Earth Pl Sc 17:1353

Gan L, Tang HF, Han YJ (2010) Geochronology and geochemical characteristics of the Yemaquan granitic pluton in east Junggar, Xinjiang. Acta Petrol Sin 26:2374-2388 (in Chinese with English abstract)

Gao S, Liu X, Yuan H, Hattendorf B, Günther D, Chen L, Hu S (2002) Determination of forty two major and trace elements in USGS and NIST SRM glasses by laser ablation-inductively coupled plasmamass spectrometry. Geostand Geoanal Res 26:181-196

Gao Y, Huang H, Tao H, Carroll AR, Qin J, Chen J, Yuan X, Wang C (2020) Paleoenvironmental setting, mechanism and consequence of massive organic carbon burial in the Permian Junggar Basin, NW China. J Asian Earth Sci 194:1-16

German CR, Elderfield H (1990) Application of the Ce anomaly as a paleoredox indicator: the ground rules. Paleoceanography 5:823833

German CR, Petersen S, Hannington MD (2016) Hydrothermal exploration of mid-ocean ridges: where might the largest sulfide deposits be forming? Chem Geol 420:114-126

Giggenbach WF (1992) Isotopic shifts in waters from geothermal and volcanic systems along convergent plate boundaries and their origin. Earth Planet Sc Lett 113:495-510

Goldstein TP, Aizenshtat Z (1994) Thermochemical sulfate reduction: a review. J Therm Anal 42:241-290

Götze J, Schertl HP, Neuser RD, Kempe U, Hanchar JM (2013) Optical microscope-cathodoluminescence (OM-CL) imaging as a powerful tool to reveal internal textures of minerals. Miner Petrol 107:373392

Gromet LP, Dymek RF, Haskin LA, Korotev HR (1984) The "north American shale composite": its compilation, major and trace element characteristics. Geochim Cosmochim Ac 48:2469-2482

Gunnarsson-Robin J, Stefánsson A, Ono S, Torssander P (2017) Sulfur isotopes in Icelandic thermal fluids. J Volcanol Geoth Res 346:161179

Habermann D, Neuser RD, Richter DK (1996) REE-activated cathodoluminescence of calcite and dolomite: high-resolution spectrometric analysis of CL emission (HRS-CL). Sediment Geol 101: $1-7$

Habicht KS, Canfield DE (2001) Isotope fractionation by sulfatereducing natural populations and the isotopic composition of sulfide in marine sediments. Geology 29:555-558

Hackley PC, Fishman N, Wu T, Baugher G (2016) Organic petrology and geochemistry of mudrocks from the lacustrine Lucaogou formation, Santanghu Basin, Northwest China: application to lake basin evolution. Int J Coal Geol 168:20-34

Han BF, Ji JQ, Song B, Chen LH, Zhang L (2006) Late Paleozoic vertical growth of continental crust around the Junggar Basin, Xinjiang, China (part I): timing of post-collisional plutonism. Acta Petrol Sin 22:1077-1086 (in Chinese with English abstract)

Han Z, Sun HT (1999) Metallogenic system of SEDEX type deposits: a review. Earth Science Frontiers 6:139-170 (in Chinese with English abstract)

He C, Ji L, Wu Y, Su A, Zhang M (2016) Characteristics of hydrothermal sedimentation process in the Yanchang formation, South Ordos Basin, China: evidence from element geochemistry. Sediment Geol 345:33-41

Hemming NG, Meyers WJ, Grams JC (1989) Cathodoluminescence in diagenetic calcites: the roles of $\mathrm{Fe}$ and $\mathrm{Mn}$ as deduced from electron probe and spectrophotometric measurements. J Sediment Petrol 59: 404-411

Jiao X, Liu Y, Wan Y, Zhou D, Li H, Nan Y, Jin M (2018) A magmatichydrothermal lacustrine exhalite from the Permian Lucaogou formation, Santanghu Basin, NW China - the volcanogenic origin of fine grained clastic sedimentary rocks. J Asian Earth Sci 156:11-25
Jiang YQ, Liu YQ, Yang Z, Nan Y, Wang R, Zhou P, Yang YJ, Kou JY, Zhou NC (2015) Characteristics and origin of tuff-type tight oil in Jimusar depression, Junggar Basin, NW China. Petrol Explor Dev 42:741-749 (in Chinese with English abstract)

Jin J, Fu H, Yu JW, Qi LQ, Shang L, Wen HH, Xu WL (2018) Sedimentary evolution of the lower Jurassic Sangonghe formation in Baijiahai uplift, Junggar Basin, and its significance in oil and gas exploration. China Petrol Explor 23:81-90 (in Chinese with English abstract)

Jochum KP, Willbold M, Raczek I, Stoll B, Herwig K (2005) Chemical characterisation of the USGS reference glasses GSA-1G, GSC-1G, GSD-1G, GSE-1G, BCR-2G, BHVO-2G and BIR-1G using EPMA, ID-TIMS. ID-ICP-MS and LA-ICP-MS Geostand Geoanal Res 29:285-302

Johannesson KH, Telfeyan K, Chevis DA, Rosenheim BE, Leybourne MI (2014) Rare earth elements in stromatolites-1. Evidence that modern terrestrial stromatolites fractionate rare earth elements during incorporation from ambient waters. In: Dilek Y, Furnes H (eds) Evolution of Archean crust and early life. Modern Approaches in Solid Earth Sciences. Springer, Netherlands, pp 385-411

Jones B, De Ronde CEJ, Renaut RW, Owen RB (2007) Siliceous sublacustrine spring deposits around hydrothermal vents in Lake Taupo, New Zealand. J Geol Soc Lond 164:227-242

Kamber BS, Webb GE (2001) The geochemistry of late Archaean microbial carbonate: implications for ocean chemistry and continental erosion history. Geochim Cosmochim Ac 65:2509-2525

Kani T, Fukui M, Isozaki Y, Nohda S (2008) The Paleozoic minimum of 87Sr/86Sr ratio in the Capitanian (Permian) mid-oceanic carbonates: a critical turning point in the late Paleozoic. J Asian Earth Sci 32:2233

Klinkhammer G, Elderfield H, Hudson A (1983) Rare earth elements in seawater near hydrothermal vents. Nature 305:185-188

Korte C, Jasper T, Kozur HW, Veizer J (2006) $87 \mathrm{Sr} / 86 \mathrm{Sr}$ record of Permian seawater. Palaeogeogr Palaeocl 240:89-107

Langmuir C, Humphris S, Fornari D, Van Dover C, Von Damm K, Tivey MK, Colodner D, Charlou J-L, Desonie D, Wilson C, Fouquet Y, Klinkhammer G, Bougault H (1997) Hydrothermal vents near a mantle hot spot: the lucky strike vent field at $37^{\circ} \mathrm{N}$ on the midAtlantic ridge. Earth Planet Sc Lett 148:69-91

Lee CA, Erdman M, Yang W, Ingram L, Chin EJ (2018) Sulfur isotopic compositions of deep arc cumulates. Earth Planet Sc Lett 500:76-85

Li H, Liu YQ, Liang H, Luo QS, Li W, Zhou XH, Jiao X, Yang R, Lei C, Sun Q (2011) Lithology and origin analysis of sublacustrine hydrothermal deposits characterized by analcime, sanidine, dolomite, quartz, etc. in Lucaogou formation, middle Permian, Santanghu Basin, Northeast Xinjiang, China. Acta Sedimentol Sin 30:205218 (in Chinese with English abstract)

Li H, Liu YQ, Zhang LX, Zhou X, Niu YZ, Li X, Liu YJ (2017) Origin and geological significance of sedimentary exhalative rocks with "porphyritic" structures in the middle Permian Pingdiquan formation, eastern Junggar Basin. J Palaeogeogr 19:211-226 (in Chinese with English abstract)

Li JY, Xiao XC, Tang YQ, Zhao M, Feng YM, Zhu BQ (1992) Metal deposits and plate tectonics in northern Xinjiang. Xinjiang Geol 10: 138-146 (in Chinese with English abstract)

Li JY, Xiao XC (1999) Brief reviews on some issues of framework and tectonic evolution of Xijiang curst, NW China. Sci Geol Sin 34(4): 405-419 (in Chinese with English abstract)

Li JY (2004) Late Neoproterozoic and Paleozoic tectonic framework and evolution of eastern Xinjiang, NW China. Geol Rev 50(3):304-322 (in Chinese with English abstract)

Liang P, Chen H, Hollings P, Xiao B, Wu C, Bao Z, Cai K (2016) The Paleozoic tectonic evolution and metallogenesis of the northern margin of east Junggar, Central Asia Orogenic Belt: Geochronological and geochemical constraints from igneous rocks of the Qiaoxiahala Fe-cu deposit. J Asian Earth Sci 130:23-45 
Liu B, Bechtel A, Sachsenhofer RF, Gross D, Gratzer R, Chen X (2017) Depositional environment of oil shale within the second member of Permian Lucaogou formation in the Santanghu Basin, Northwest China. Int J Coal Geol 175:10-25

Liu B, Bechtel A, Gross D, Fu X, Li X, Sachsenhofer RF (2018) Middle Permian environmental changes and shale oil potential evidenced by high-resolution organic petrology, geochemistry and mineral composition of the sediments in the Santanghu Basin, Northwest China. Int J Coal Geol 185:119-137

Liu X, Dalton SH, Timothy WL, Swart PK (2019) Evaluating the fidelity of the cerium paleoredox tracer during variable carbonate diagenesis on the great Bahamas Bank. Geochim Cosmochim Ac 248:25-42

Liu XM, Gao S, Diwu CR, Yuan HL, Hu ZC (2007) Simultaneous in-situ determination of U-Pb age and trace elements in zircon by LA-ICPMS in $20 \mu \mathrm{m}$ spot size. Chin Sci Bull 52:1257-1264

Liu YQ, Li H, Zhu YS, Hu T, Fu GB, Liu HF, Zhou XH, Zheng CY, Fan TT (2010) Permian lacustrine eruptive hydrothermal dolomites, Santanghu Basin, Xinjiang Province. Acta Sedmentologica Sinica 28:861-867 (in Chinese with English abstract)

Liu YQ, Jiao X, Li H, Yuan MS, Yang W, Zhou XH, Liang H, Zhou DW, Zheng CY, Sun Q, Wang SS (2012) Mantle exhalative hydrothermal original dolostones of Permian, in Yuejingou section, Santanghu area, Xinjiang province. Sci China Earth Sci 55:183-192

Lyons TW, Gellatly AM, McGoldrick PJ, Kah LC (2006) Proterozoic sedimentary exhalative (SEDEX) deposits and links to evolving global ocean chemistry, in Kesler, S.E., and Ohmoto, H., eds., evolution of early Earth's atmosphere, hydrosphere, and biosphereconstraints from ore deposit. Geol Soc Am Mem 198:169-184

Martin W, Baross J, Kelley D, Russell MJ (2008) Hydrothermal vents and the origin of life. Nat Rev Microbiol 6:805-814

McCarthy KT, Pichler T, Price RE (2005) Geochemistry of champagne Hot Springs shallow hydrothermal vent field and associated sediments, Dominica, Lesser Antilles. Chem Geol 224:55-68

Meng CS, He ZH, Wu JH, Pan XQ (1992) Classification and correlation of Permian and Mesozoic in Junggar Basin. Xinjiang Petrol Geol 13: 161-170 (in Chinese with English abstract)

Mills RA, Elderfield H (1995) Rare earth element geochemistry of hydrothermal deposits from the active TAG mound, $26^{\circ} \mathrm{N}$ midAtlantic ridge. Geochim Cosmochim Ac 59:3511-3524

Möller P, Bau M (1993) Rare-earth pattern with positive cerium anomaly in alkaline waters from Lake Van, Turkey. Earth Planet Sc Lett 117: $671-676$

Niu Y, O’ Hara MJ (2009) MORB mantle hosts the missing Eu (Sr, Nb, $\mathrm{Ta}$ and $\mathrm{Ti}$ ) in the continental crust: new perspectives on crustal growth, crust-mantle differentiation and chemical structure of oceanic upper mantle. Lithos 112:1-17

Ohmoto H, Lasaga AC (1982) Kinetics of reactions between aqueous sulfates and sulfides in hydrothermal systems. Geochim Cosmochim Ac 46:1727-1745

Othman DB, White WM, Patchett JP (1989) The geochemistry of marine sediments, island arc magma genesis, and crust-mantle recycling. Earth Planet Sc Lett 94:1-21

Olivarez AM, Owen RM (1991) The europium anomaly of seawater: implications for fluvial versus hydrothermal REE inputs to the oceans. Chem Geol 92:317-328

Parekh PP, Möller P, Dulski P, Bausch WM (1977) Distribution of trace elements between carbonate and non-carbonate phases of limestone. Earth Planet Sc Lett 34:39-50

Peters M, Strauss H, Farquhar J, Ockert C, Eickmann B, Jost CL (2010) Sulfur cycling at the mid-Atlantic ridge: a multiple sulfur isotope approach. Chem Geol 269:180-196

Qiu Z, Zou C, Dong D, Lu B, Shi Z, Tao H, Zhou J, Lei D, Zhang C (2016b) Petroleum system assessment of conventionalunconventional oil in the Jimusar sag, Junggar basin, Northwest China. J Unconv Oil Gas Res 16:53-61
Qiu Z, Tao H, Zou C, Wang H, Ji H, Zhou S (2016a) Lithofacies and organic geochemistry of the middle Permian Lucaogou formation in the Jimusar sag of the Junggar Basin, NW China. J Pet Sci Eng 140: 97-107

Qu GS, Ma ZJ, Shao XZ, Zhang XK (2008a) Basement and crust structures in Junggar Basin. Xinjiang Petrol Geol 29:669-674 (in Chinese with English abstract)

Qu GS, Ma ZJ, Zhang N, Li T, Tian Y (2008b) Fault structures in and around Junggar Basin. Xinjiang Petrol Geol 29:291-295 (in Chinese with English abstract)

Rees CE, Jenkins WJ, Monster J (1978) The Sulphur isotope composition of ocean water sulphate. Geochim Cosmochim Ac 42:377-381

Sakai H, Des Marais DJ, Ueda A, Moore JG (1984) Concentrations and isotope ratios of carbon, nitrogen, and sulfur in ocean-floor basalts. Geochim Cosmochim Ac 48:2433-2441

Sarangi S, Mohanty SP, Barik A (2017) Rare earth element characteristics of Paleoproterozoic cap carbonates pertaining to the Sausar group, Central India: implications for ocean paleoredox conditions. J Asian Earth Sci 148:31-50

Seal RR II (2006) Sulfur isotope geochemistry of sulfide minerals. Rev Mineral Geochem 61:633-677

Shanks WC III, Callender E (1992) Thermal springs in Lake Bakal. Geology 20:495-497

Shanks WC III (2001) Stable isotopes in seafloor hydrothermal systems: vent fluids, hydrothermal deposits, hydrothermal alteration, and microbial processes. Rev Mineral Geochem 43:469-525

Song XX, Xu QS, Guo YM (1997) REE geochemistry of VMS and SEDEX ores in China. Acta Geol Sin-Engl 71:263-272

Stucker VK, de Ronde CEJ, Scott BJ, Wilson NJ, Walker SL, Lupton JE (2016) Subaerial and sublacustrine hydrothermal activity at Lake Rotomahana. J Volcanol Geoth Res 314:156-168

Su YP, Zheng JP, Griffin WL, Tang HY, O' Reilly SY, Lin XY (2010) Zircon $\mathrm{U}-\mathrm{Pb}$ and $\mathrm{Hf}$ isotopes of volcanic rocks from the Batamayineishan formation in the eastern Junggar Basin. Chin Sci Bull 55:2931-2943

Subba Rao DV, Naqi SM (1997) Geological setting, mineralogy, geochemistry and genesis of the middle Archaean Kalyadi copper deposit, western Dharwar craton, southern India. Mineral Deposita 32: 230-242

Sun SS, McDonough WF (1989) Chemical and isotopic systematics of oceanic basalts: implications for mantle composition and processes. Geol Soc London Spec Publ 42:313-345

Sverjensky DA (1984) Europium redox equilibria in aqueous solution. Earth Planet Sc Lett 67:70-78

Takai K, Horikoshi K (1999) Genetic diversity of archaea in deep-sea hydrothermal vent environments. Genetics 152:1285-1297

Tiercelin JJ, Pflumio C, Castrec M, Boulègue J, Gente P, Rolet J, Coussement C, Stetter KO, Huber R, Buku S, Mifundu W (1993) Hydrothermal vents in Lake Tanganyika, east African rift system. Geology 21:499-502

Veizer J (1989) Strontium isotopes in seawater through time. Annu Rev Earth Pl Sc 17:141-167

Wang J, Wu C, Zhu W, Li Z, Wu J, Chen R, Wang J (2016) Tectonicdepositional environment and prototype basin evolution of the Permian-Triassic in southern Junggar Basin. J Palaeogeogr 18(4): 643-660 (in Chinese with English abstract)

Watt GR, Wright P, Galloway S, Mclean C (1997) Cathodoluminescence and trace element zoning in quartz phenocrysts and xenocrysts. Geochim Cosmochim Ac 61:4337-4348

Wen HG, Zheng RC, Qing HR, Fan MT, Li YN, Gong BS (2013) Primary dolostone related to the cretaceous lacustrine hydrothermal sedimentation in Qingxi sag, Jiuquan Basin on the northern Tibetan plateau. Sci China-Earth Sci 56:2080-2093

Whitney DL, Evans BW (2010) Abbreviations for the names of rockforming minerals. Am Mineral 95:185-187 
Woodruff LG, Shanks WC III (1988) Sulfur isotope study of chimney minerals and vent fluids from $21^{\circ} \mathrm{N}$, East Pacific rise: hydrothermal sulfur sources and disequilibrium sulfate reduction. J Geophys Res 93:4562-4572

Wu H, Hu W, Cao J, Wang X, Wang X, Liao Z (2016) A unique lacustrine mixed dolomitic-clastic sequence for tight oil reservoir within the middle Permian Lucaogou formation of the Junggar Basin, NW China: reservoir characteristics and origin. Mar Petrol Geol 76:115132

Wu XQ, Liu DL, Wei GQ, Li J, Li ZS (2009) Geochemical characteristics and tectonic settings of carboniferous volcanic rocks from LudongWucaiwan area, Junggar Basin. Acta Petrol Sin 25:55-66

Xiao W, Han C, Yuan C, Sun M, Lin S, Chen H, Li Z, Li J, Sun S (2008) Middle Cambrian to Permian subduction-related accretionary orogenesis of northern Xinjiang, NW China: implications for the tectonic evolution of Central Asia. J Asian Earth Sci 32:102-117

Xie W, Luo Z, Xu Y, Chen Y, Hong L, Ma L, Ma Q (2016) Petrogenesis and geochemistry of the late carboniferous rear-arc (or back-arc) pillow basaltic lava in the Bogda Mountains, Chinese north Tianshan. Lithos 244:30-42

Xu XY, Li BS, Chen JL, Ma ZP, Li ZP, Wang HL, Bai JK, Tang Z (2014) New constrains on the Paleozoic tectonic evolution of the northern Xinjiang area. Acta Petrol Sin 30(6):1521-1534 (in Chinese with English abstract)

Yang GX, Li YJ, Wu HE, Si GH, Ji Z, Zhang YZ (2009) LA-ICP-MS zircon $\mathrm{U}-\mathrm{Pb}$ dating of the Huangyangshan pluton and its enclaves from Kalamaili area eastern Junggar, Xinjiang, and geological implications. Acta Petrol Sin 25(12):3197-3207 (in Chinese with English abstract)

Yang PR, Yang WQ, Meng YY, Feng QL (2007b) Lower carboniferous stratigraphic system of Kelamaili Orogenic Belt, Xinjiang and its tectonic setting. Geological Science and Technology Information 26:6-10 (in Chinese with English abstract)

Yang W, Liu YQ, Feng Q, Lin JY, Zhou DW, Wang D (2007a) Sedimentary evidence of early-late Permian mid-latitude continental climate variability, southern Bogda Mountains, NW China. Palaeogeogr Palaeocl 252:239-258
Yang W, Feng Q, Liu YQ, Tabor N, Miggins D, Crowley LJ, Lin JY, Thomas S (2010) Depositional environments and cyclo- and chronostratigraphy of uppermost carboniferous - lower Triassic fluvial - lacustrine deposits, southern Bogda Mountains, NW China - a terrestrial paleoclimatic record of mid-latitude NE Pangea. Glob Planet Chang 73:15-113

Yang XQ, Zhang ZH, Duan SG (2018) Origin of the Mesoproterozoic Jingtieshan bedded barite deposit, north Qilian Mountains, NW China: geochemical and isotope $(\mathrm{O}, \mathrm{S}, \mathrm{Sr})$ evidence. Geol J 53(S1):21-32

Yang Z, Zhong DK, Whitaker F, Lu Z, Zhang S, Tang ZH, Liu RC, Li Z (2020) Syn-sedimentary hydrothermal dolomites in a lacustrine rift basin: petrographic and geochemical evidence from the lower cretaceous Erlian Basin, North China. Sedimentology 67:305-329

Zeng Z, Ma Y, Chen S, Selby D, Wang X, Yin X (2017) Sulfur and lead isotopic compositions of massive sulfides from deep-sea hydrothermal systems: implications for ore genesis and fluid circulation. Ore Geol Rev 87:155-171

Zheng J, Wang F, Cheng Z, Wu X, Zhang Y (2000) Nature and evolution of amalgamated basement of Junggar Basin, northwestern China: $\mathrm{Sr}-\mathrm{Nd}$ isotope evidences of basement igneous rock. Earth ScienceJournal of China University of Geosciences 25(2):179-185 (in Chinese with English abstract)

Zheng RC, Wen HG, Fan MT, Wan MF, Wu GX, Xia PF (2006) Lithological characteristics of sublacustrine white smoke type exhalative rocks of the Xiagou formation in Jiuxi Basin. Acta Petrol Sin 22:3027-3038 (in Chinese with English abstract)

Zhong DK, Jiang ZC, Guo Q, Sun HT, Yang Z (2015) Discovery of hydrothermal dolostones in Baiyinchagan sag of Erlian Basin, Inner Mongolia, and its geologic and mineral significance. Oil Gas Geol 36:587-595 (in Chinese with English abstract)

Zou C, Zhu R, Chen ZQ, Ogg JG, Wu ST, Dong D, Qiu Z, Wang Y, Wang L, Liu S, Cui J, Su L, Yang Z (2019) Organic-matter-rich shales of China. Earth-Sci Rev 189:51-78

Publisher's note Springer Nature remains neutral with regard to jurisdictional claims in published maps and institutional affiliations. 